\title{
CXCR4/CXCR7 Molecular Involvement in Neuronal and Neural Progenitor Migration: Focus in CNS Repair
}

JOSÉ JOAQUÍN MERINO, ',2* VICTOR BELLVER-LANDETE,' MARÍA JESÚS OSET-GASQUE, ${ }^{1,2}$ AND BEATRIZ CUBELOS ${ }^{3 * *}$

'Biochemistry and Molecular Biology Dept II, Universidad Complutense de Madrid (UCM), Madrid, Spain

${ }^{2}$ Instituto de Investigación, Neuroquímica (IUIN), UCM, Madrid, Spain

${ }^{3}$ Departamento de Biología Molecular, Centro de Biología Molecular Severo Ochoa (CBMSO), Universidad Autónoma de Madrid, Madrid, Spain

In the adult brain, neural progenitor cells (NPCs) reside in the subventricular zone (SVZ) of the lateral ventricles, the dentate gyrus and the olfactory bulb. Following CNS insult, NPCs from the SVZ can migrate along the rostral migratory stream (RMS), a migration of NPCs that is directed by proinflammatory cytokines. Cells expressing CXCR4 follow a homing signal that ultimately leads to neuronal integration and CNS repair, although such molecules can also promote NPC quiescence. The ligand, SDFI alpha (or CXCLI2) is one of the chemokines secreted at sites of injury that it is known to attract NSC-derived neuroblasts, cells that express CXCR4. In function of its concentration, CXCLI 2 can induce different responses, promoting NPC migration at low concentrations while favoring cell adhesion via EGF and the alpha 6 integrin at high CXCLI2 concentrations. However, the preclinical effectiveness of chemokines and their relationship with NPC mobilization requires further study, particularly with respect to CNS repair. NPC migration may also be affected by the release of cytokines or chemokines induced by local inflammation, through autocrine or paracrine mechanisms, as well as through erythropoietin (EPO) or nitric oxide (NO) release. CXCLI2 activity requires G-coupled proteins and the availability of its ligand may be modulated by its binding to CXCR7, for which it shows a stronger affinity than for CXCR4.

J. Cell. Physiol. 230: 27-42, 20I5. (C) 2014 Wiley Periodicals, Inc.

Neuronal progenitor cells (NPCs) can differentiate into neurons, astrocytes or oligodendrocytes, and they can promote the survival/integration of cells into new neuronal circuits after CNS insult (Fallon et al., 2000). Neurogenesis occurs in specific areas of the brain (Altman and Das, 1965),

Abbreviations: AMD3100, plerixafor; AMPc, cyclic AMP; Ang-I, angiopoietin; $\mathrm{BBB}$, blood-brain barrier; BRAK/CXCLI4, breastand kidney-expressed chemokine/CXC chemokine ligand I4; BDNF, brain-derived neurotrophic factor; CNS, central nervous system; CCL2/MCP-I, monocyte chemotactic protein-I; CD34 ${ }^{+}$, hematopoietic progenitor cell antigen; CXCR4, (C-C motif) receptor 4; CCR5, (C-C motif) receptor 5; CNTF, ciliary neurotrophic factor; CREB, (cAMP response element-binding protein); CuxI/2, cut-like homeodomain transcription factor family I/2; CXCR6, Chemokine (C-X-C motif) receptor 6; CXCLI2 CXCLI2 (SDFI alpha), stromal cell derived factor I alpha; EGF, epidermal growth factor; EFGR, Epidermal growth factor receptor; EPO, erythropoietin; FGF-2, basic fibroblast growth factor-2; GCL, granular cell layer; GABA, gamma-aminobutyric acid; GFAP, glial fibrillary acidic protein (GFAP); ICAM, intercellular adhesion molecule-I; LIF, leukemia inhibitory factor; II-8, interleukin 8; ILI Beta, interleukin-I beta (IL- I $\beta$ ); I-TAC, interferon-inducible T cell alpha chemoattractant; IFN gamma, Interferon gamma; G-CSF, granulocyte colony-stimulating factor; HSC, hepatic stellate cells; LFA-I, lymphocyte function-associated antigen I; MBEC, mouse brain endothelial cells; MAPK/CREB, mitogen-activated protein kinase/cAMP response element-binding protein; MMP2/9, metalloproteinase 2/9; PDGF, platelet-derived growth factor; NGF, nerve growth factor; NO, nitric oxide; NPC, neural progenitor cells; PC, preconditioning; PPAR $\gamma$, peroxisome proliferatoractivated receptor gamma; ROS, reactive oxygen species; OB, olfactory bulb; PCNA, proliferating cell nuclear antigen; PSANCAM, polysialylated neuronal cell adhesion molecule; RMS, rostral migratory stream; si-RNA (CXCR4), RNA interference including the subventricular zone (SVZ) of the lateral ventricles and the subgranular zone (SGZ) of the granular cell layer (Gould et al., I 999; Bernier et al., 2002; Gould, 2007 Coremans et al., 20I0; Pignatelli and Belluzzi, 20I0; Walton et al., 20I3). Functional recovery from insult requires the integration of new

(CXCR4); SGZ, subgranular zone; SVZ, subventricular zone; rhEPO, human recombinant erythropoietin; VEGF, vascular endothelial growth factor.

The authors have no conflict of interests to declare.

Contract grant sponsor: SAF 2012-3/279 and RyC 2008-0258. Contract grant sponsor: RyC 2010-0625I.

[Correction added on 7 October 2014, after first online publication 29 September 2014: The citation year has been corrected to 2015.]

*Correspondence to: José Joaquín Merino, Department of Biochemistry and Molecular Biology II, School of Pharmacy, Instituto Universitario de Investigación Neuroquímica (IUIN), Universidad Complutense de Madrid (UCM), cl Ciudad Universitaria s/n, 28080 Madrid, Spain.

E-mail: josem2005@yahoo.es

**Correspondence to: Beatriz Cubelos, Departamento de Biología Molecular, Universidad Autónoma de Madrid, Centro de Biología Molecular Severo Ochoa (CBMSO), Campus de Cantoblanco Universidad, c/ Einstein 3, 28049 Madrid, Spain.

E-mail: bcubelos@cbm.csic.es

Manuscript Received: 18 September 2013

Manuscript Accepted: 3 June 2014

Accepted manuscript online in Wiley Online Library (wileyonlinelibrary.com): 10 June 2014.

DOI: $10.1002 /$ jcp. 24695 
neurons into the existing and/or damaged circuits, which depends on their correct migration (Decimo et al., 20I2). Under non-pathological conditions, most NPCs can produce interneurons in the olfactory bulb (OB): (Christie and Turnley, 20I3; Walton et al., 20I3), and new neurons are derived from less-differentiated neural stem/progenitor cells (NSCs) and neuroepithelial cells (NEPs) that differentiate into neuronalrestricted or glial-restricted precursor cells (Bonaguidi et al., 2005, 2008; Stephens et al., 20I2). NPCs express nestin (a neuroepithelial cell marker) and musashi-I, a neural RNA binding protein, while undifferentiated NEPs express specific transcription factors, such as Sox I, Sox2, and Sox3 (Foshay and Gallicano, 2008; Sundberg et al., 20II).

\section{Which Signals Induce NPC Migration toward Damaged} Areas of the CNS?

Several extrinsic and intrinsic factors that emanate from the SVZ can regulate neurogenesis when inflammation arises as a result of CNS damage (Whitney et al., 2009; Gonzalez-Perez et al., 20 I0; Boneva and Yamashima, 20I2; Gensel et al., 20I2). Many such factors regulate the fate and proliferation of NSCs in the neurogenic niches, including nerve growth factor (NGF), bFGF (basic fibroblast growth factor) or FGF-2 (basic fibroblast growth factor) (Schwindt et al., 2009; Bohrer and Schwertfeger, 20I2), BDNF (brain-derived neurotrophic factor) (Zhang et al., 20I I), Neurotrophin-4/5 (NT3 and NT4/ $5)$, ciliary neutrophic factor (CNTF), vascular endothelial growth factor (VEGF), erythropoietin (EPO), leukemia inhibitory factor (LIF) (Oshima et al., 2007), BMI-I and plateletderived growth factor (PDGF- $\alpha$ ) (Lowenstein and Arsenault, 1996; Jo et al., 2000; Kijowski et al., 200 I; Coskun and Luskin, 2002; Aguirre et al., 2005; Bonaguidi et al., 2005; Bauer and Patterson, 2006; Liu et al., 2006; Dempsey and Kalluri, 2007; Covey and Levison, 2007; Liu et al., 2007; Krüger et at., 2007; Bonaguidi et al., 2008; Choi et al., 2008; Lum et al., 2009; Leong and Turnley, 201 I; Reed et al., 2012; Koivuniemi et al., 2013; Talaverón et al., 20I3; Sánchez-Mendoza et al., 20I3). In this review, we shall examine how chemokines influence NPC migration within the SVZ following injury and CNS damage (Wang et al., 2002; Imitola et al., 2004; Merino et al., 20I la). Chemotactic factors promote neurogenesis and gliogenesis in the normal developing brain (Réaux-Le Goazigo et al., 20I3), and the CXCR4/CXCLI 2 (SDFI) axis induces NPC differentiation and migration in the periinfarct area (Imitola et al., 2004; Dziembowska et al., 2005; Tran et al., 2007; Turbic et al., 20I I). The response of SVZ-derived NPC, and of the new cells they produce, is quite variable, depending on the type of injury, the brain area damaged and the trophic factor/s released following damage, such as cytokines (Hagberg and Mallard, 2005), chemokines (Bonecchi et al., 2009) or vascular factors (Schanzer et al., 2004; Bauer, 2009). Thus, cell therapy could possibly promote the migration of SVZ neuroblasts that express the CCRI-8, 10 and/or CXCRI-6 chemokine receptors and their ligands (Tran et al., 2007). Most of the research into chemokines has been carried out in rodent models, studying the ectopic migration and neural differentiation of SVZ-derived NPCs following the neural damage produced by cerebral ischemia ( $\mathrm{Li}$ et al., 2012; Lindvall et al., 2004; Lichtenwalner and Parent, 2006). In these models, the enhanced NPC motility induced by chemokines and growth factors guides neuroblasts from the SVZ/RMS toward the damaged areas in the CNS (Merino et al., 2008, 20 I Ib; Turbic et al., 20I I), with CXCR4 co-localizing with PSA-NCAM in the migrating cortical neurons (Merino et al., 2008). Some chemokines have anti-apoptotic effects and they promote neurogenesis in rodent models of cerebral ischemia (Imitola et al., 2004; Liu et al., 2007, 2008a,b; Merino et al., 20 I la). Consequently, both endogenous and grafted NPCs can migrate and differentiate into new neurons according to different chemotactic gradients (Li et al., 20I3; Liu et al., 2008). The signaling mechanisms by which chemokines regulate differentiation, cell remodeling and self-repair in pathological circumstances in the CNS may potentially promote recovery to some extent (Bye et al., 20I2; Gensel et al., 20I2; Hassani et al., 2012). Indeed, proliferation is a feature associated with stem cell transplantation during the first week post-lesion in rodent models of global ischemia (Levison et al., 200I; Chen et al., 200 I, 2004; Bonecchi et al., 2009). However, the poor survival of new neurons in the lesioned area (Arvidsson et al., 2002), together with the limited integration of newly-formed cells into existing neural circuits more than four weeks after their implantation, are issues that limit the efficacy of cell therapy in neurodegenerative diseases (Aboody et al., 2000; Stroemer et al., 2009; Perederiy et al., 2013). In fact, several weeks after transplantation proliferation rates return to normal (Thored et al., 2006; Kokaia and Lindvall, 2003). Thus, it is crucial to elucidate how chemokines direct neuroblast migration and the interaction of these cells with their environment (Robin et al., 2006; Tiveron et al., 2006; Barkho and Zhao, 2010), particularly in a neuropathological context (Fiala et al., 20I2).

In the present review, we will concentrate on how molecular regulators of the CXCR4/CXCR7/CXCLI 2 regulate NPC migration and CNS repair, and the extent to which crosstalk between the nervous and immune systems might regulate these processes (Klein and Rubin, 2004). Several chemokines are expressed in the vascular niche (CCRI-3, 5, 7-I0 and CXCRI-4), as well as in neurospheres (CCRI-8, 10 and CXCRI-6: (Tran et al., 2007; Bonecchi et al., 2009). Chemotactic factors direct NPC migration after striatal damage, these include monocyte chemoattractant protein-I (MCP-I, CCL-2), and growth regulated oncogene-alpha (GRO alpha) (Gordon et al., 2009). Interestingly, CXCR4 signaling induces survival and migration of neural and oligodendrocyte precursors (OP) during embryonic and postnatal CNS development. In fact, in CXCR4-defective mice, the number of neural precursors in the neurosphere outgrowth was twofold less than in wild-type mice; Neural precursor radial cell migration was also decreased in these mices (Lu et al., 2002; Dziembowska et al., 2005). However, the addition of recombinant CXCLI 2 protein to neurospheres derived from wild type mice increases the radial migration of cells from the sphere in a dose-dependent manner (Dziembowska et al., 2005). In these studies, fewer differentiated oligodendrial cells expressing platelet-derived growth factor receptor (PDGFR) were found in the CXCR4-deficient mice (Dziembowska et al., 2005). These observations support a role for chemokines in NPC migration and repair. Indeed, the release of CXCLI 2 and its interaction with CXCR4 promotes migration from neurospheres derived from EI7 embryonic or adult mouse NPCs (Robin et al., 2006) Figure IA shows neurosphere cultures at 5 days in vitro and Figure $\mathrm{Ib}$ and $\mathrm{c}$ indicates neuroblast and immature neurons derived from them.

Chemokines are small chemotactic cytokines that interact with specific G-protein coupled receptors (CCR., CXCR, CX3CR, CR) and regulate leukocyte or immune cell trafficking to damaged areas of the CNS (Asensio and Campbell, 1999). Proinflammatory cytokines act as neuromodulators/ neurohormones, and they can regulate processes such as synaptic transmission (Banisadr et al., 20I I), migration, and NPC proliferation by providing autocrine/paracrine survival signals (Rostene et al., 2007); Figure 2 shows all regulators of CXCR4. For instance, other BRAK/CXCLI 4 chemokines also regulate synaptic transmission in the adult dentate gyrus (Banisadr et al., 20II). The chemokine BRAK (CXCLI4) is an ancient member of the chemokine family whose functions in the brain are completely unknown. CXCLI 4 is a small cytokine 

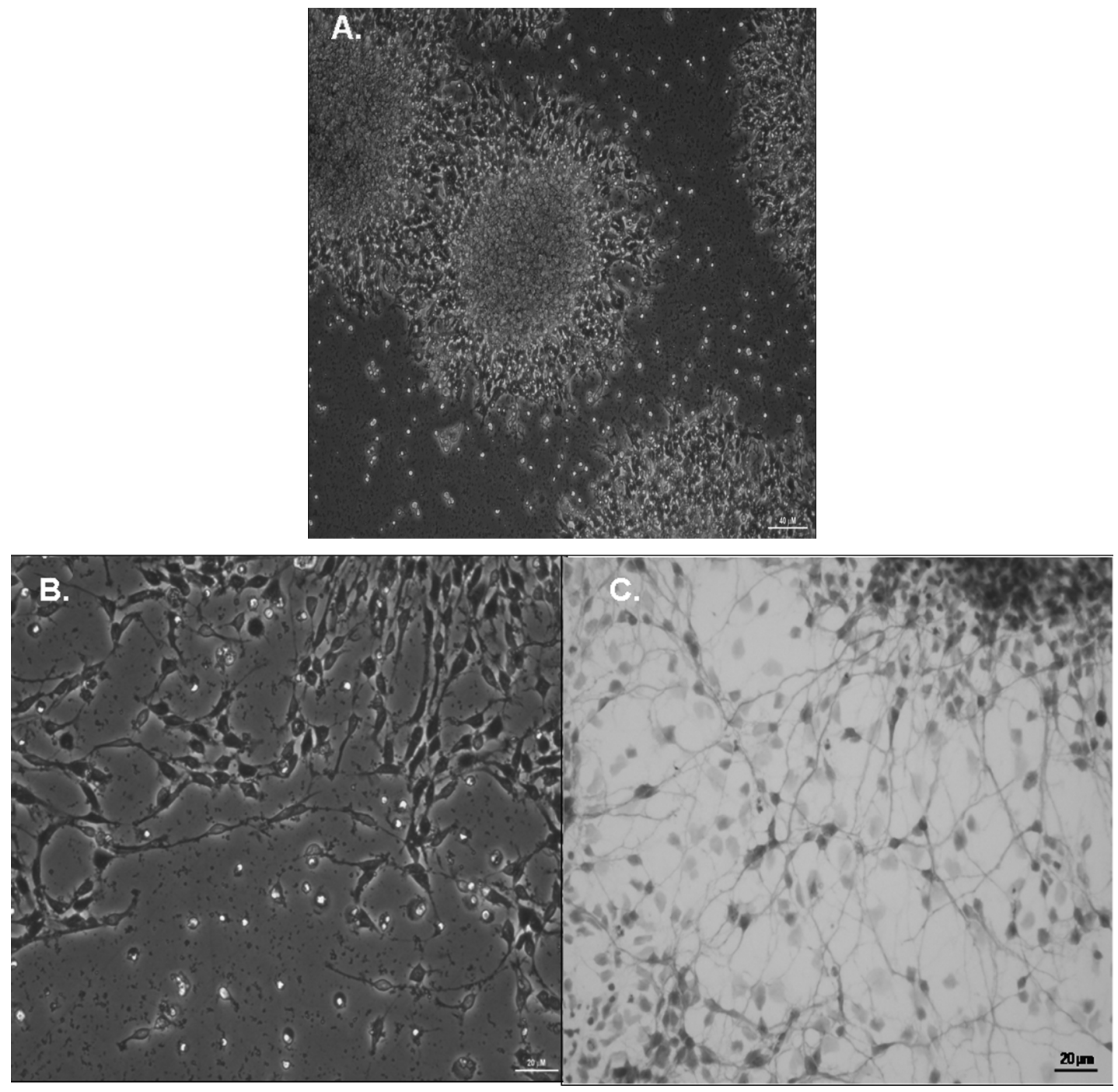

Fig. I. (A) SVZ Neurospheres after 5 days of differentiation in primary culture. Phase-contrast image of neurosphere with cells invading the space between them. $(B, C)$ Neuroblasts and immature neurons in vitro at 5 days of culture.

belonging to the CXC chemokine family that is also known as BRAK (for breast and kidney expressed chemokine).

Chemokines can also regulate the capacity to adapt migratory patterns in response to changes in the surrounding environment (Otto et al., 2002; Hallbergson et al., 2003; ji et al., 2004b; Bye et al., 20I2). Neurogenesis via the CXCR4/

CXCLI 2 interaction, and that provoked by other chemokines (e.g., monocyte chemotactic protein I [CCL2] [Li et al., 2008]), induces the migration and differentiation of NPCs within the SVZ in periinfarct areas following cerebral ischemia (Arvidsson et al., 2002; Zhang et al., 2002; Ni et al., 2004; Robin et al., 2006; Ohab et al., 2006; Liu et al., 2008). However, chemokines such as CXCLI 2 or CX3CLI/fractalkine can promote NPC quiescence (qNPC) (Krathwohl and Kaiser, 2004a,b), as well in hematopoietic stem cells (HSCs; Broxmeyer et al., 2003).

\section{Do NPCs Promote Functional Recovery in Neurogenic Areas Following CNS Insult?}

The transition from quiescence to self-renewal or differentiation is a response to specific cues or factors (Kiel and
Morrison, 2008; Christie and Turnley, 2013). For example, two weeks after injury, newly-generated neuroblasts re-route from the SVZ and RMS to the lesion, where they can differentiate to form mature neurons in rodents (Lindvall et al., 2004; Kokaia et al., 20I2; Kokaia and Lindvall, 20I3). These SVZ-derived neuroblasts can replace damaged neurons in the hippocampus, striatum, and neocortex (Takasawa et al., 2002; Jin et al., 2005; Tonchev et al., 2005; Kuge et al., 2009), and they can differentiate into neurons, oligodendrocytes, or astrocytes. The NPCs that originate in the SGZ can be identified by a combination of brain lipid binding protein (BLBP), nestin and glial fibrillary acidic protein (GFAP), and most NPCs express the markers Nestin and Sox2 (llieva and Dufva, 20I3).

Subsequently, the majority of these NPCs differentiate into immature doublecortin positive $(D C X+)$ neurons (or neuroblasts) and mature $\mathrm{NeuN}+$ neurons, which can integrate into hippocampal networks as fully functional neurons (Bye et al., 2012; Lacar et al., 20I2).

The SVZ is a three-dimensional interconnected niche that is made up of three major cell types (Lacar et al., 20I2). The formation and proliferation of NPCs is dependent on the Sox 


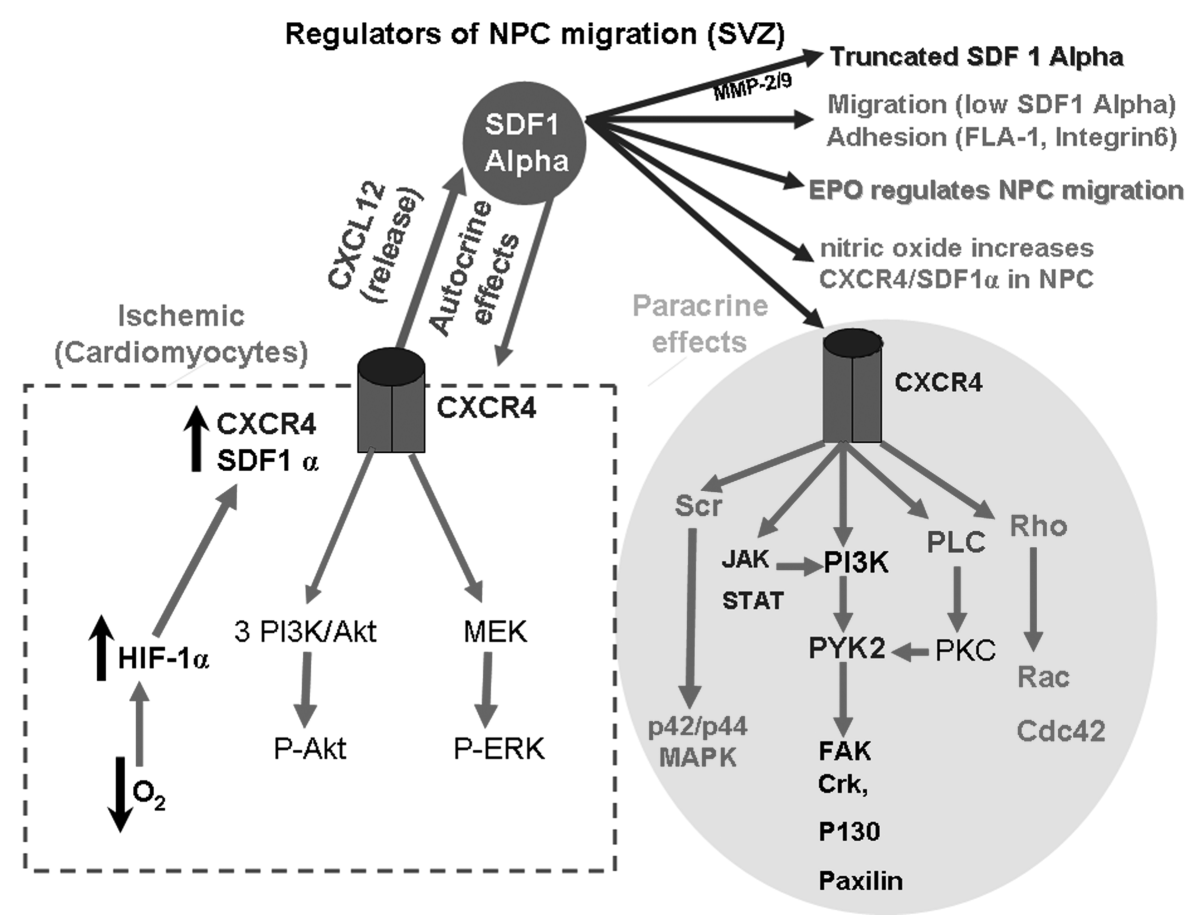

Fig. 2. Molecular modulators of CXCR4/CXCR7 chemokines in neuronal repair and neuroblast recuruitment. SDFI Alpha (CXCLI2) can induce NPC migration at low concentrations while favoring cell adhesion via EGF and the alpha 6 integrin (at high CXCLI 2 levels). Cytokines/ chemokines regulate NPC migration through autocrine/paracrine mechanisms. In addition, erythropoietin (EPO) or nitric oxide release (NO) release also regulate CXCR4/CXCLI 2 axis. Finally, CXCLI 2 activity requires G-coupled proteins and its availability may be modulated by its binding to CXCR7. For instance, hypoxia increases CXCR4/CXCLI 2 levels (left part) while CXCLI2 can induce p-akt or p-ERK cascades (CXCR4 +) (left part) or activate other signaling pathways in cardiomyocytes (Jak/Rho/PKC, right part). CXCLI 2/CXCR4 signal axis plays pleiotrophic effects (right part). Molecular CXCR4/CXCR7 regulators (upper part).

gene family, in particular Sox2 (Andreu-Agullo et al., 20I I). Neuroblasts (DCX + type A cells) are organized into a network that is ensheathed by the processes of qNSCs (nestin + and GFAP + type B cells) and that arises from rapidly amplifying NPCs (Nestin + and GFAP + type C cells (Kim et al., 2007; Leong and Turnley, 20II; Saaltink et al., 20I2).

In the adult SVZ, NPCs are associated with ependymal and vascular niches that regulate stem cell self-renewal and differentiation. Activated type B stem cells and their progeny (Lacar et al., 20I2), the transitory amplifying type $C$ cells, express epidermal growth factor receptor (EGFR) (Abhold et al., 20I2), and are most strongly associated with vascular cells (Miller and Gauthier-Fisher, 2009). Adult qNSCs (type B cells) in the SVZ and subgranular zone (SGZ) share basic properties with embryonic radial glia (RG: Miller and GauthierFisher, 2009), and upon transplantation into neurogenic areas of the adult brain (the hippocampus and (OB), these NPCs can differentiate into new neurons in response to local signals released by neurons following CNS insult (Carbajal et al., 20 I0; Bye et al., 20I2).

The development of the CNS requires the formation of numerous, precise connections between neurons and their targets. Newly born neurons from the neocortex can undertake radial migration through the embryonic cortex, whereas tangential migration is a glial-guided process of neuronal translocation that occurs throughout the developing brain but that only persists in the RMS of adult brains (Boldajipour et al., 2008; Christie and Turnley, 20I3). These neuroblasts migrate long distances from the SVZ to the olfactory bulb through a glial tunnel formed by astrocytes
(Snapyan et al., 2009; Fig. 3). Both actively dividing type B and type $C$ cells are closely associated with the vascular niche in the SVZ (Shen et al., 2008; Tavazoie et al., 2008). Rapidly dividing type $C$ cells give rise to type $A$ neuroblasts, progenitors that divide as they migrate, usually in cell chains. In the dorsal SVZ, neuroblast chains often run parallel to blood vessels in the direction of the RMS (see Fig. 3: Shen et al., 2008; Tavazoie et al., 2008) and the OB (Snapyan et al., 2009). Upon arrival at the $\mathrm{OB}$, neuroblasts switch to radial migration in order to reach their final destination. However, a cortical injury may

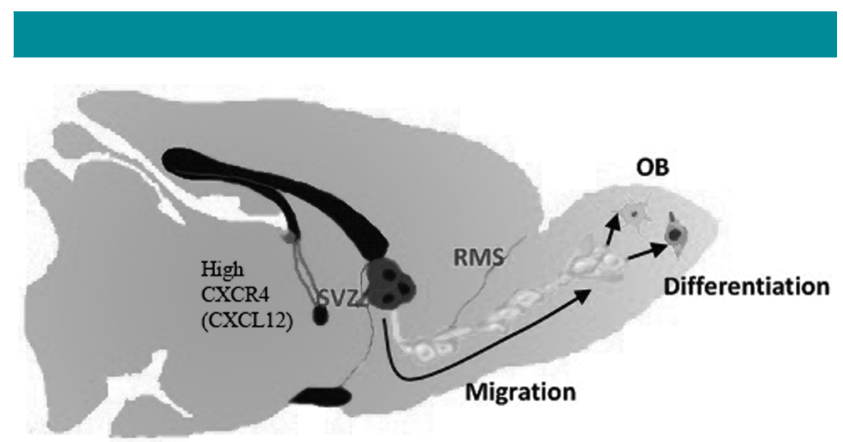

Fig. 3. Scheme of the neural cell migration process from the Subventricular zone (SVZ) toward the olfactory bulb (OB). 
change the migration patern switching it from tangencial to radial migration (Goings et al., 2004).

In the CNS, CXCLI2 chemokine directs migration to the cerebellum (Ma et al., 1998) or granular cell layer (Lu et al., 2000; Bagri et al., 2002; Tran et al., 2007). In addition, CXCLI2 signaling is required for the maintenance of Cajal-Retzius cell position in the marginal zone during normal cortical development (Paredes et al., 2006; Berger et al., 2007). The CXCR4/CXCR7/CXCLI 2 axis also directs cortical neuronal migration (Tham et al., 200 I; Stumm et al., 2003; Li et al., 2008; López-Bendito et al., 2008; Tiveron and Cremer, 2008); CXCLI 2 is overexpressed by GABAergic neurons from the SVZ GABAergic neurons from the SVZ (Bhattacharyya et al., 2008; Casoni et al., 2012). Indeed, ectopic migration in the granular cell layer occurs in transgenic mice lacking CXCR4 (Lu et al., 2002). CXCR4 is expressed by dividing NPCs from the SGZ, as well as by their derivatives, including doublecortinexpressing neuroblasts and immature granule cells (Bhattacharyya et al., 2008). CXCLI2 induces post-synaptic transmission in parvalbumin-containing GABAergic interneurons (basket cells from the dentate gyrus). CXCLI2 was located in the synaptic vesicles of basket cells and in GABAcontaining vesicles, which suggests that $C X C L I 2$ regulates the strength of the GABAergic inputs to the pool of dividing neural progenitors from the dentate gyrus (Bhattacharyya et al., 2008), and that CXCLI 2 signaling directly regulates the migration of neuroblasts within the RMS (Kokovay et al., 20I I). Axonal processes from differentiated neurons are guided to their targets by families of repellent and attractant signaling molecules (Tessier-Lavigne and Goodman, 1996; Yu and Bargmann, 200I). Interestingly, CXCLI 2 plays an important role in modulating axonal responsiveness to several guidance cues through CXCR4 and a cyclic nucleotide-dependent (AMPc) signaling pathway (Chalasani et al., 2003a,b).

Chemokines like CCL2 direct the migration of NPCs in neuroinflammatory conditions (Belmadani et al., 2006). The CXCR4/CXCLI 2 chemokine attracts HSCs (hematopoietic stem cells) to pass from the blood to the bone marrow, and it retains stromal cells within the bone marrow niche (Voermans et al., 200 Ia,b; Chute, 2006; Chu et al., 2007; Rose et al., 2008). CXCLI2-induced progenitor migration in hematopoietic progenitor cells bearing CXCR4 chemokine receptor (Voermens et al., 200 Ia). Stromal cell secretion of CXCLI2 creates a gradient that leads to actin polymerization and integrin overexpression, resulting in chemotaxis toward the source of the CXCLI 2 (Voermans et al., 200 la,b).

Protective actions mediated by immune cells though chemokine release could regulate responses in the neural microenvironment that promote tissue repair in damaged areas of the CNS (Klein and Rubin, 2004; Giusto et al., 20I3). On the other hand, through CXCLI2 release, the CXCLI2CXCR4 axis regulates the recruitment of endothelial progenitors (CD34+) during inflammation (Modle et al., 1998; jo et al., 2000). In this context, CXCLI 2 might enhance the immune and CNS systems during immune and CNS development, favoring their co-ordinated activity (Klein and Rubin, 2004).

Does CXCLI 2 Regulate the Adherence of NPCs to Blood Vessels and/or Their Migration Along Chemotactic Gradients?

Through different signaling pathways, CXCLI 2 is involved in regulating quiescence, activation, migration, and homing (Krathwohl and Kaiser, 2004a,b; Wong and Korz, 2008). CXCLI 2 regulates stem cell migrations that occupy and leave niches in different vascularized parenchymal regions of the CNS. In normal conditions, the cells in these niches can be coopted to enhance repair when NSCs home to the vasculature through an CXCLI2/CXCR4 dependent mechanism. NPCs can become integrated when transplanted into the adult SVZ or hippocampus, and they generate neurons via CXCLI 2 (Gage et al., 1995; Belmadani et al., 2005), as well as binding preferentially to endothelial cells in function of a chemotactic gradient (Warner et al., 2008).

CXCLI 2 is a chemoattractant for cortical neurons and meningeal cells (Borrell and Marín, 2006), although it also induces cortical migration (Tham et al., 200I; Lazarini et al., 2003; Stumm et al., 2004; Tissir et al., 2004; Daniel et al., 2005). Indeed, CXCLI 2 promotes NPC migration within the SVZ along endothelial cells depending on the available CXCLI 2 and CXCR4 (Zhu et al., 2002). CXCLI 2 is secreted by meningeal cells and acts as a chemotactic factor for NSCs in the external cerebellar granular layer, as well as for NPCs (Reiss et al., 2002) and hematopoietic precursors (Aiuti et al., 1997). Interestingly, CXCLI 2 deficiency induces ectopias in the cerebellum, suggesting that perhaps CXCLI 2 chemotactically attracts neuronal cells isolated from the cerebellar external granular layer (EGL), but not from the internal granular cell layer (IGL) (Reiss et al., 2002). These CXCLI 2 mediated chemoattractant effects were abolished by removal of CXCLI 2 from conditioned media by immunoprecipitation, and they could be restored by the addition of recombinant CXCLI 2 (Reiss et al., 2004). These findings indicate the relevance of the chemoattractant capacity of CXCLI 2 for neurons (Reiss et al., 2004).

CXCLI 2 and CXCR4 are involved in actin reorganization and the cell migration mediated by endothelial progenitor cells after PAR-I activation (Smadja et al., 2005). CXCLI2 is the most important chemoattractant for hematopoietic stem/ progenitor cells (Aiuti et al., 1997; Kucia et al., 2005) since CXCR4 blockade by AMD3I00 (a chemokine blocker), or CXCR4 knockdown by siRNA CXCR4, effectively blocks homing of activated type $B$ and type $C$ cells to blood vessels (Aiuti et al., 1997; Kucia et al., 2005). Cells expressing CXCLI2 are found in the SVZ and they express the PCNA cell-cycle marker. Indeed, proliferating CXCLI 2 cells co-localize with the nuclear CuxI/2 marker exclusively in the SVZ/IZ and cortex (Tiveron et al., 2006; Cubelos et al., 2008), and they play a role in cortical migration and dendritogenesis (Nieto et al., 2004 Cubelos et al., 20 I0). Collectively, these findings demonstrated the relevance of CXCR4/CXCR7 (SDFI) alpha chemokines in neuronal migration (Wang et al., 20II).

How do Niche-dependent CXCLI 2 Levels Induce Stem-cell Differentiation and Adhesion, and Promote Cell Migration after CNS Damage?

Curiously, high CXCLI 2 levels in the ependymal layer could help induce quiescence, as occurs in vascular cells (Siegenthaler and Pleasure, 20I0). The differential CXCLI 2 gradient could regulate NPC quiescence when CXCLI 2 is abundant, especially since CXCR4 can induce fast desensitization and internalization of this alpha chemokine receptor (SánchezMartín et al., 2013). Conversely, low CXCLI2 levels induce differentiation and proliferation in the SVZ (Dar et al., 2005; Lapidot et al., 2005). In fact, CXCLI2 strongly upregulates EGFR (epidermal growth factor receptor) and alpha6 integrin in activated type $B$ and type $C$ cells, enhancing their activated state and their ability to bind laminin in the vascular niche (Siegenthaler and Pleasure, 2010 : Fig. 4). Once SVZ type B stem cells become activated and express EGFR, they are chemically attracted to the surface of blood vessels. It is seems that the upregulation of EGFR in activated type $B$ cells by $\mathrm{CXCLI} 2$ favors chemotaxis (Porcile et al., 2005; Abhold et al., 20I2). CXCLI 2 can induce SVZ migration via EGFR since crosstalk between EGFR and CXCR4 signaling promotes proliferation (Porcile et al., 2005; Guo et al., 2007). Thus, CXCLI 2 increases 


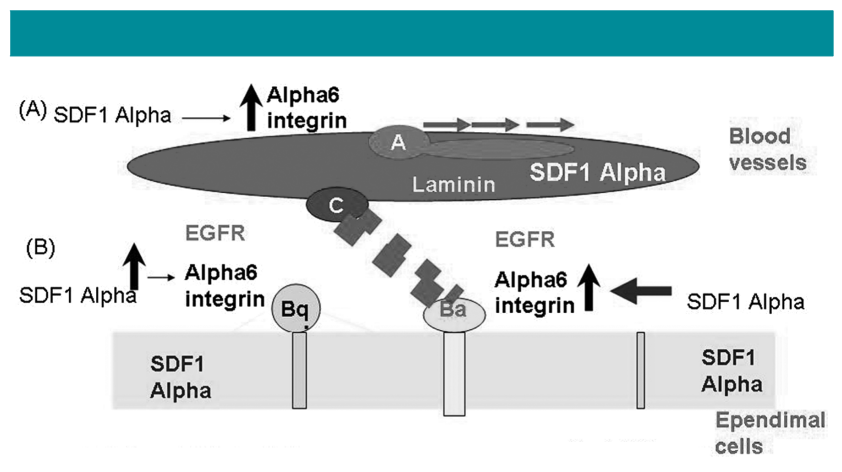

Fig. 4. (A) Stem cell niche quiescent $B$ cells $(B q)$ are in a subependymal position with their apical process contacting the ventricular space. $(\mathrm{B})$ Once activated $(\mathrm{Ba})$, these cells generate transiently amplifying $C$ cells positioned in close proximity to blood vessels. Both the ependyma and vessels express SDFI alpha (CXCLI2), which regulates proliferation through EGFR and cell ahdhesion ( $\alpha 6 \beta I$, integrin). C cells generate $A$ cells, which them migrate toward the olfactory bulb (OB) through the rostral migratory stream (RMS).

the motility of type A neuroblasts and induces NPC migration from the SVZ toward the OB (Kokovay et al., 20I0;

Siegenthaler and Pleasure, 20I0). Consequently, CXCLI2 regulates progenitor cell occupancy and exit from the adult SVZ through its activity within vascular niches (Siegenthaler and Pleasure, 20I0; Fig. 4).

Alternatively, CXCLI 2 is concentrated by heparan sulfate proteoglycans (Amara et al., 1999; Netelenbos et al., 2003) and LFA-I (lymphocyte function associated antigen-I), as well as by other cell adhesion molecules involved in CXCLI 2 triggered proadhesive interactions in T lymphocytes (Wu et al., 20I2).

Regulation of integrin activity maintains the ability of lymphocytes to adhere quickly at sites of infection or inflammation (Wu et al., 20I2). Indeed, quiescent type B NSCs are the only cell type that do not display chemotaxis toward CXCLI 2 or endothelial cell-conditioned medium. However, activated $B$ cells remain in close proximity to blood vessels in the SVZ, and particularly C cells, while type A cells migrate toward the OB (Miller and Gauthier-Fisher, 2009). In this context, chemokines like IL-8 or CXCLI 2 induce the recruitment of human NPCs across brain endothelial cells (Weiss et al., 20I0). In addition, CXCLI6 induces migration and invasion by glial precursor cells via its CXCR6 chemokine receptor (Hattermann et al., 2008).

Both ependymal and vascular cells provide important factors for NPC regulation. Noggin (expressed by ependymal cells) induces neurogenesis (Lim et al., 2000) and PDGF (secreted by both ependymal and blood vessels) supports self-renewal (Ramirez-Castillejo et al., 2006). Interestingly, only activated type $B$ and type $C$ cells that are dividing are enriched near blood vessel surfaces (Tavazoie et al., 2008). In fact, the ependymal niche harbors quiescent stem cells, while the vascular niche regulates the transit-amplifying type $C$ cells and type $A$ neuroblasts, which are more strongly attracted to endotheliumderived factors than are quiescent stem cells (Fig. 4)

On the other hand, CXCLI 2 stimulates type $A$ cells in the SVZ to move toward blood vessels and these type A cells are not normally as close to the vascular surface as activated type $B$ and type $C$ cells. Although type $A$ cells are chemically attracted to endothelial factors, their migratory capacity is less effectively blocked by AMD3I00 (a CXCR4 antagonist), suggesting that additional chemoattractant(s) are required for NSC homing to endothelial cells in the SVZ (Miller and Gauthier-Fisher, 20I2; Tavazoie et al., 2008). Moreover, CXCLI2 upregulates alpha 6 integrin expression on activated type $B$ and type $C$ cells, albeit less so on type $A$ cells. These differential effects on type $A, B$ or $C$ cells may explain how stem cell trafficking of NPCs toward blood vessels is mediated through an CXCLI 2 gradient. Thus, certain concentrations of CXCLI 2 could promote type $A$ egression and migration from the vascular niche toward the $O B$ (Snapyan et al., 2009). In this respect, it is important to elucidate how CXCLI 2 stimulates CXCR4 signaling pathways and NPC migration, issues that are discussed below.

\section{Which Signaling Pathways are Involved in CXCLI 2 Proliferative Effects in NPC?}

The coupling of CXCR4 to different intracellular pathways depends on its activation by its ligand CXCLI 2 (Khan et al., 2003). Thus, we will briefly describe the cascades involved in CXCLI2-mediated NPC proliferation in vitro (i.e., PI-3 kinase/ Akt, JAK/STAT pathways, or FOXO-3 activation; Fig. 5).

\section{CXCLI 2 induces NPC migration through Akt-I and FOXO3a phosphorylation}

It is known that the PI3K/Akt-I pathway contributes to the proliferation or self-renewal of embryonic stem cells (Paling et al., 2004) and CXCR4 activation regulates second messenger activity through Gi-Go GTP-binding proteins, since PTX (an inhibitor of $G$ proteins) decreased CXCLI2-induced NPC proliferation in vitro (Wu et al., 2004). It has been shown that the CXCR4/G protein/PI3K-Akt pathways are responsible for CXCLI2-mediated NPC proliferation (Fig. 5), through the phosphorylation of Akt-I and FOXO3a (Wu et al., 2009; Yumei et al., 2009). Several studies in vitro reported that CXCR4 activation by CXCLI 2 induces neuronal survival through $A k t$ phosphorylation (activation) and that this can also regulate cellcycle proteins in post-mitotic neurons (e.g., Retinoblastoma; Rb: Khan et al., 2003, 2008). Akt-I (a serine/threonine kinase) is a downstream target of PI3K, a kinase known to regulate the survival and proliferation of various cell types, including NPCs (Nakamura et al., 2000; Chang et al., 2003; Brunet et al., 2009). The transcription factor FOXO3a (a downstream target of Akt-I) is directly associated with CXCLI 2 mediated human NPC proliferation. FOXO3a is one of the FOXO subclass of Forkhead transcription factors (Forkhead box, class $O$ : Birkenkamp et al., 2007) and CXCLI 2 increases the phosphorylation of Akt-I and FOXO3a (Wu et al., 2009). As a major substrate of Akt-I, FOXO3a plays a critical role in coordinating cell survival or cell death reponses (Nakamura et al., 2000; Birkenkamp et al., 2007). Thus, one way in which Akt-I may promote cell survival and proliferation is through FOXO3a phosphorylation (Yang et al., 2008b). CXCR4 antagonist (TI40) or inhibitors for $\mathrm{G}$ proteins (pertussis toxin, PTX) and PI3K (LY294002) abolished CXCL I2-mediated NPC proliferation and phosphorylation of Akt-I and FOXO3a (Wu et al., 2004, 2009). In conclusion, CXCR4 activation by CXCLI 2 is coupled to $G$ proteins and p-Akt regulates the proliferative effects of CXCLI 2 on NPCs in vitro (Fig. 5).

The role of $\mathrm{PI} K \mathrm{~K}$ ( $\mathrm{PIIO \alpha}$ and $\mathrm{pI} I 0 \beta$ catalytic subunits) in NPC migration via CXCR4/CXCLI 2 signaling

The two catalytic subunits of PI3K, pIIO $\alpha$ and $p I I O \beta$, are both activated by EGF (epidermal growth factor) CXCLI 2 in vitro, and the $\beta$ isoform of PI3K is responsible for NPC movement toward chemoattractants. PI3K ( $\mathrm{PI} \mid O \beta)$ is activated by CXCLI 2 in NPCs and its activity is necessary for immature interneuron migration to the cerebral cortex. However, pl I0 $\beta$ was not necessary for pyramidal neuron migration, suggesting that the dependence of migration on $\mathrm{pl} I 0 \beta$ is cell type and/or chemoattractant dependent in vivo (Holgado et al., 2013). 


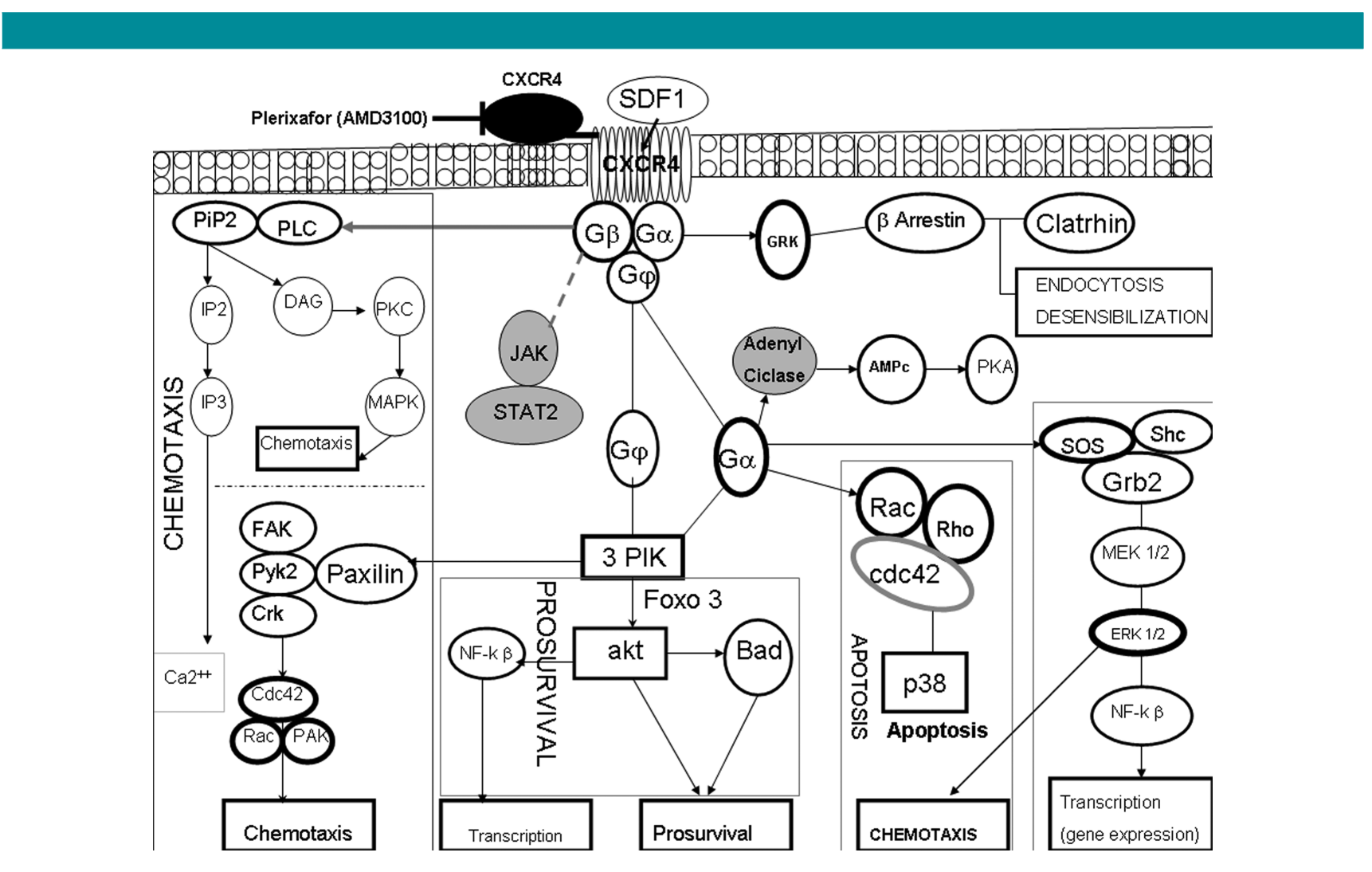

Fig. 5. CXCR4 signaling pathways. CXCR4 induces chemotaxis via Cdc42/Rac or p-ERK I/2 cascade (right part). Foxo3a and akt phosphorylation promotes survival in NPC bearing CXCR4 chemokine receptor. CXCLI 2 plays an essential role in modulating axonal responsiveness to several guidance cues through a cyclic nucleotide-dependent signaling pathway (AMPc). Chemokines also mediates chemotaxis via STAT-2/JAK cascade. Clatrin mediates endocytoses (CXCR4+ cells). AMD3 I00 (a CXCR4 chemokine blocker) blocks CXCLI2-induced migration in NPC.

\section{CXCLI 2 and JAK/STAT or FAK signaling in NPCs}

NPCs respond to CXCLI 2 by activating the JAK (Janus kinases), $\mathrm{PI} 3 \mathrm{~K}$ and ERK-I/2 pathways, all signaling cascades associated to CXCR4 in cells of the immune system but also, in NPCs in vitro (Vila-Coro et al., 1999; Balabanian et al., 2005; Schabath et al., 2006; Guillermet-Guibert et al., 2008; Fig. 5). Jaks are a small family of cytoplasmic tyrosine kinases, critical for signaling by Type I and II cytokine receptors. The JAK/STAT pathway is another pathway activated by CXCLI 2 in NPCs in vitro (Holgado et al., 20I3; Fig. 5) and NPC proliferation and differentiation are differentially regulated by the Jak pathway (Jin et al., 2005, 2006). CXCLI 2 induced JAK2 activation and STAT5b association to CXCR4. CXCLI2-induced NPC migration is blocked by the JAK2 Inhibitor II or the pan-JAK inhibitor (AG490), as reported for T cells (Soriano et al., 2003). In fact, Jak2 regulates NPC proliferation and maintenance, whereas silencing of JAK3 signaling is essential for NPC differentiation into neurons and oligodendrocytes (Kim et al., 2007, 2010). Moreover, STAT3 activation in NPCs leads to astrogliogenesis (Peng et al., 2012; Chen et al., 20I3) and indeed, after CXCL 12 binding, JAK2 and JAK3 associate with CXCR4 and are activated (Vila-Coro et al., 1999). Activation of the JAK/ STAT pathway by other chemokines has been described, including CCR2 (Mellado et al., 1998), CCR7 (Mellado et al., 2003; Stein et al., 2003) CCR5 (Wong and Fish, 1998; Wong and Korz, 2008) and CXCR4 (Vila-Coro et al., 1999).

Although the JAK/STAT pathway was activated following CXCLI 2 stimulation of NPCs, JAK activity was not necessary for NPC migration in vitro. Interestingly, JAK2 or JAK3 deficiency does not alter the CXCLI 2 responses in immune cells (Moriguchi et al., 2005). It has also been suggested that JAK is necessary for CXCLI2-mediated STAT recruitment (Ahr et al., 2005). Interestingly, CXCLI 2 might require the JAK/ STAT pathway to trigger neural precursor differentiation induced by IL-6 (Miller and Gauthier, 2007).

ERK-I/2 is another cascade involved in cell migration (Delgado-Martin et al., 20I I), connecting the PI3K and MAPK signaling pathways (Lopez-llasaca et al., 1997; Bondeva et al., 1998; Gong et al., 2006). ERK-I/2 activation occurs in NPCs treated with TGX-22I in vitro (a pl IO $\beta$ inhibitor), suggesting that some crosstalk could exist between these two signaling cascades. In fact, CXCL I2-mediated NPC migration decreased after treatment with a specific ERK-I/2 pathway inhibitor, while p I IO $\beta$ knockdown blocked CXCLI2-induced migration (Holgado et al., 2013). Collectively, these findings indicate that several signaling cascades are involved in the influence of CXCLI 2 on NPC migration (CXCR4+; Khan et al., 2003; Peng et al., 2004; Fig. 5).

Another cue regulating NPC migration is the homing cascade that determines cell adhesion to brain endothelial cells and transendothelial migration for cell repair (Cui et al., 2007). In this context, metalloproteases (MPP2/9) regulate the trafficking of stem cells (Son et al., 2006). Since the CXCR4/ CXCLI 2 axis mediates active MMP9 and MMP2 secretion in different cell types (Yu et al., 2003; Chu et al., 2007), the chemotaxis seems to be regulated MMP and CXCR4 in vitro (Cui et al., 2007). Accordingly, we must consider how MPP2/9 activation contributes to the regulation of chemokine activity (Mastroianni et al., 20II). 
Does Chemokine and Metalloprotease Activity Regulate NPC Migration Toward Damaged Areas of the CNS?

MMPs are a family of metalloendopeptidases that cleave the protein components of the extracellular matrix (ECM) under pathological conditions (Mastroianni and Liuzii, 2007). However, these proteins can also promote tissue repair, remodeling or neurogenesis (Canete-Soler et al., 1995a,b). MMPs are members of the $\mathrm{Zn}$-dependent endopeptidase family, and their expression is transcriptionally controlled by proinflammatory cytokines (cytokines or chemokines), growth factors, hormones, and cell-cell and cell-matrix interactions (Van den Steen et al., 2002; Nagase, 1997). It is noteworthy that MMP-2 activation cleaves CXCLI 2 into a neurotoxic isoform (the truncated SDF-I (5-67) that reduces NPC proliferation (Zhang et al., 2003; Barkho et al., 2008; Lum et al., 2009; Peng et al., 20I3; Fig. 2). CXCLI2 induces CXCR4 activation and promotes NPC migration by activating ERKI/2 and Akt-I, decreasing cAMP levels (Peng et al., 20 I3; Holgado et al., 20I3). However, its SDF-I (5-67) truncated form (generated by metalloprotease MMP2/9) fails to induce NPC migration and it does not activate these signaling pathways (Peng et al., 20I3). Interestingly, activation of CXCR 4 by CXCLI 2 depends on two domains located at the $\mathrm{N}$-terminal of this alpha chemokine receptor (PepC-C: KPVSLSYRCPCRFFESHIARA). This synthetic peptide upregulates $C X C L I 2$ expression in vivo and in vitro, promote chemotaxis of neuroblasts in vivo, and stimulate chemotaxis and proliferation of CXCR4+ cells in vitro, without affecting NSC fate (Filippo et al., 20I3). Thus, post-translational CXCLI 2 cleavage by MMP-2 generate a neurotoxic SDF-I (5-67) form that could reduce NPC migration and induce

neurotoxicity (Peng et al., 2000, 2012; Zhang et al., 2003). Conversely, the Metalloproteinase 17 (ADAMI7), also known as Tumor necrosis factor- $\alpha$ Converting enzyme is primarily involved in CXCLI2-induced shedding from neurons in vitro (Simizu et al., 20I0). Moreover, CXCLI 2 can provoke the cleavage of other chemokines, like fractalkine (CX3CLI, a delta chemokine), by enhancing ADAMI 7 expression in cortical neurons in vitro. Thus, CXCLI 2 regulates the expression of ADAMI7 rather than directly stimulating its enzymatic activity in cortical neurons in vitro suggesting that MMP activation regulates CXCLI 2 levels in neural cells (Simizu et al., 20I0).

How do Metalloproteases Control the Trafficking of Stem Cells Through CXCR4/CXCLI 2 Chemokines?

Circulating stem cells release factors that enable them to cross the endothelial barrier and home to an organ (e.g., MMP2 or MMP9: Kucia et al., 2006). Several studies have demonstrated that MMPs regulate the chemotaxis of progenitor cells through the CXCR4/CXCLI2 axis. In fact, MMPs play a role in the CXCLI2/CXCR4-induced chemotaxis of human hematopoietic progenitor cells across subendothelial basement membranes, a process that is blocked by MMP inhibitors (Janowska-Wieczorek et al., 2000). Indeed, the intracerebral injection of recombinant human CXCLI 2 stimulates the homing of transplanted bone marrow stromal cells (BMSCs) to the site of injection in the brain (Jin et al., 2006). Since CXCLI 2 enhances the chemotaxis of bone marrow and blood CD34 (+) cells (Mohle et al., 1998), and this chemotaxis can be blocked by inhibitors of MMPs (Lin et al., 2013; Chambon et al., 2013), these findings indicate that the activation of metalloproteases regulates the chemotaxis of progenitor cells via the CXCR4/CXCLI 2 axis.

Nitric Oxide (NO) and CXCLI2 Regulation: A Role in Repair?

NO produced by eNOS (endothelial nitric oxide synthase) plays a role in angiogenesis and vascular remodeling, and eNOS is also essential for the mobilization of stem and progenitor cells (Aicher et al., 2003), as well as promoting neurogenesis/ repair in rodent models of stroke (Zhang et al., 2004; Chen et al., 2005). Interestingly, CXCLI2-induces chemotaxis in $\mathrm{T}$ cells by a mechanism mediated by $\mathrm{NO}$ signaling (Aicher et al., 2003). In fact, the CXCLI $2 / C X C R 4$ axis mediates the DETANONOate ([Z]-I-[N-(2-aminoethyl)-N-(2-ammonioethyl) aminio] diazen-I-ium-I,2-diolate) enhancement of BMSCs for CNS repair, along with MMP9, by increasing CXCLI 2 and Angiopoietin I (Ang I) levels in the SVZ: Zacharek et al., 2006, 2007; Cui et al., 2007). This evidence indicates that NO donors significantly enhance CXCL I2-induced cell migration in rodent models of cerebral ischemia (Cherla and Ganju, 200 I; ji et al., 2004a; Zhou et al., 2007). Since CXCR4 blockade or MMP inhibition significantly attenuate DETA-NONOate-induced BMSC migration, CXCR4 and MMP appear to fulfill a crucial role of in the control of NPC migration (Ciu et al., 2007). Indeed, a higher density of secreted MMP9 was evident in SDSpolyacrylamide gel electrophoresis zymography after DETANONOate treatment of synergic BMSCs, suggesting that chemokines and MMPs regulate the chemotaxis of progenitor cells. In consonance with this hypothesis, AMD3 100 (a CXCR4 chemokine blocker) or GM600I (an MMP inhibitor) significantly attenuated DETA-NONOate-induced BMSC adhesion to mouse brain endothelial cells (MBECs) or astrocytes (Ciu et al., 2007).

\section{Erythropoietin (EPO) Regulates CXCR4 (CXCLI2)} Levels Through Specific Signaling Pathways

This glycoprotein and its cognate receptor, EPOR, offer protection against insults in the CNS, and EPO is another factor that regulates CXCR4/CXCLI 2 expression (Keswani et al., 2005; Tsai et al., 2006; Liao et al., 2008; Chamorro et al., 20I3). Since EPO promotes neurogenesis and can induce neuroblast migration from the SVZ toward the OB after CNS damage (Shingo et al., 200I; Chen et al., 2007; Ransome and Turnley, 2007), it may fulfill a fundamental therapeutic role in cerebral ischemia by regulating CXCR4/CXCLI 2 levels (Wang et al., 2004; Avasarala and Konduru, 2005; Xiong et al., 2007; Brunner et al., 2009).

Ischemic stroke is an example of a CNS pathology where chemokines promote angiogenesis and NPC recruitment (Amantea et al., 2009; Merino et al., 20 I I; 20I3). Stroke is one of the major causes of disability in adults, and is the result of cerebral artery occlusion and blood-brain barrier dysfunction. During the initial phase of cerebral ischemia, inflammatory responses, gliosis, and microglial overactivation occur, provoking an increase in NO and ROS production that leads to neurodegeneration (Zhang et al., 200I; Itoh et al., 2009; Chaturvedi and Kaczmarek, 20I3). In the neurovascular niche, MMPs secreted by endothelial cells can breakdown the tight junctions between astrocytes and the endothelium (Venstrom and Reichardt, 1993; Asahi et al., 200I; Ohab et al., 2006; Reuter et al., 20I3).

Interestingly, CXCR4 and MMP9 expression can induce both beneficial (Liu et al., 20I2) or detrimental effects in the developing and adult brain (Kim et al., 2006; Liu et al., 2008) or spinal cord (Pannu et al., 2007). Since inflammation is detrimental for neurogenesis (Ekdahl et al., 2003) and IL-8, CCL-2, CCR5, leukotriene B4 -LTB4-, and CXCLIchemokines or cell adhesion molecules (ICAM, Selectin, CDII/CDI8 integrins) induce leukocyte recruitment toward damaged CNS areas (Kim, 1996; Kang et al., 20I2; Ma et al., 20I2), it is important to elucidate how EPO regulates chemokines to guide NPC migration from the SVZ toward the damaged CNS and promote repair (Bye et al., 20I2). This feature might be important from a therapeutic view point because TPA (the recombinant tissue plasminogen activator; 
a thrombolytic factor) is currently the only clinical agent approved for stroke therapy (Saver et al., 2013).

It is also crucial to study the pathways by which EPO signaling induces chemokine-dependent NPC migration. In this context, NSCs respond to injury by secreting CXCR4/CXCLI2, and the cytokines IL-I Beta, IL-6, TNF- $\alpha$, IL-4, and IL- I 0 (Filippo et al., 20I3). Cytokine-mediated deployment of CXCLI 2 induces revascularization through the recruitment of CXCR4+ hemangiocytes (Jin et al., 2006). Since rhEPO-activated endothelial cells enhance NPC migration by secreting MMP2 and MMP9, and by PI3K/Akt activation in vitro, Akt could mediate EPO-induced neuroprotection following insult. However, EPO also induces ERKI/2 signaling, as well as MMP2 and MMP9 secretion (Wang et al., 2006). Since rhEPO-treated MBEC supernatants (conditioned medium) promote the migration of NPCs, an effect that is abolished by MMP inhibitors, EPO might also regulate NPC migration (Asahi et al., 200 I; Wang et al., 2004, 2008). Moreover, EPO induces the phosphorylation of FOXO3a via the PI3K/Akt cascade and it leads to the proteolysis that retains it in the cytoplasm by binding to 14-3-3 protein (Chong and Maiese, 2007). It is noteworthy that the protection mediated by EPO against insults in vitro occurs through $3 \mathrm{PI}-$ kinase/Akt activation and $\mathrm{NO}$ release. $\mathrm{NO}$ generated by $\mathrm{nNOS}$ also triggers the release of EPO following insult, and this is prevented by (TRIM) a specific neuronal nNOS inhibitor in vitro (Keswani et al., 2004). In fact, the beneficial effects of rhEPO on post-ischemic progenitor migration are potentially mediated via MPP2 and/or MPP9 secretion, as well as by the phosphoinositol-3-kinase/ Akt I (Cai and Semenza, 2004; Fig. 2) and ERKI/2 signaling pathways (Wang et al., 2006). However, PI3K/Akt and the ERKI/2 inhibitors attenuated the rhEPO-induced MMP2 and MMP9, which suppressed NPC migration promoted by the rhEPO-activated MBECs (Wang et al., 2006). Therefore, EPOinduced NPC migration was dependent on MMPs in endothelial cells (Wang et al., 2006). The reparative role of EPO is consistent with the reported neurite elongation and neuroprotective role induced by peripheral administration of EPO (Pankratova et al., 20I2), which promotes neurogenesis, oligodendrogenesis and neurovascular remodeling following traumatic brain injury, and that has a favorable functional outcome in rats (for review, Brettschneider et al., 2006; Kadota et al., 2009). However, there are concerns about the potential clinical use of EPO as it increases hematocrit at the doses required for neurogenesis in rodent models $(5000 \mathrm{U} / \mathrm{kg})$, although this adverse effect was abolished by its Carbamylated EPO derivate, which promotes proliferation in the SVZI dentate gyrus and the neuronal differentiation of adult NPCs (Wang et al., 2006; Leconte et al., 20I I), as well as SVZ-derived oligodendrogenesis (Kako et al., 20I2). Interestingly, in cerebral models of ischemia enhanced homing of bone marrow-derived progenitor cells through the CXCR4/ CXCLI 2 axis was induced by the neuroprotectant cerebrolysin in cardiomyocytes (Brunner et al., 2009) and neuronal cells in vivo and in vitro (Merino et al., 2009). Since Increased Sca-I $(+)$ and CXCR4(+) homing, and BMSC mobilization, were directed toward an CXCLI 2 gradient in the ischemic myocardium, these findings would support the notion that EPO promotes protective effects via CXCR4/CXCLI2 chemokines (Brunner et al., 2009; Gao et al., 20I2).

How Differential CXCLI 2 Binding via CXCR4 and CXCR7 Regulates NPC Migration/How Does CXCR4CXCR7 Crosstalk Regulate NPC Migration?

The expression of different chemokine receptors on the same cell can lead to the formation of heterodimers that may enhance or reduce the effects of the chemokines (Percherancier et al., 2005). CXCR7 (RDCI) is the second receptor for CXCLI2, a receptor that fails to couple to classic G-protein signaling pathways activated by chemokines (Ehrlich et al., 20 I3). However, it remains unclear how CXCR7 acts as a scavenger receptor to reduce the availability of CXCLI 2 for CXCR4 or CXCR7 signaling in NPCs (Boldajipour et al., 2008; Zhu et al., 20I2). The chemoattractant properties of NPCs from the SVZ vary in function of the CXCLI 2 concentration. In fact, CXCLI 2 has an approximately 10-fold higher affinity for CXCR7 than for CXCR4 (Bakondi et al., 20 I I; Costantini et al., 20I3) and, while CXCR7 regulates the responses to CXCLI 2 in culture cells, CXCR4 can form heterodimers with CXCR7 (Levoye et al., 2009). CXCR7 is a second and de-orphanized CXCLI 2 receptor that mediates the anti-apoptotic signaling effects of CXCLI 2 (Kalatskaya et al., 2009; Sánchez-Martín et al., 20I3). In this way, CXCLI 2 can signal through CXCR7 in large populations of SVZ NPCs that express both these alpha chemokine receptors (Zhu et al., 20I2). Indeed, CXCLI2 secreted by human CDI33-derived multipotent stromal cells promotes NPC survival by activating CXCR7 (Bakondi et al., 2012).

Thus, the existence of a balance between CXCR dimers and monomers at the membrane could explain why the CXCLI 2 axis promotes NPC or neuronal migration (Costantini et al., 20I3). CXCR7 is expressed by neurons, astroglia and vascular cells in the forebrain, suggesting that $\mathrm{CXCLI} 2$ may signal through CXCR7 in large populations of neural cells (Schönemeier et al., 2008). CXCR7 expression was found to be regulated by the membrane level of CXCR4 (Wang et al., 2008), although activated chemokine receptors are desensitized (Lagane et al., 2005, 2008) and internalized before they are subsequently degraded in the endosome or are recycled back to the cell surface (Kucia et al., 2005a,b). Most CXCR7 receptors are found in early endosomes (Wysoczynski et al., 2005; Hartmann et al., 2008) and thus, the surface expression of this chemokine appears to be regulated at the translational level by modulating its intracellular transport and incorporation into the membrane (at the post-translational level: Sánchez-Martín et al., 20I3). Ubiquitination may also regulate CXCR7 trafficking to and from the plasma membrane since CXCR7 is reversibly de-ubiquitinated upon CXCLI 2 recombinant exposure, and it can even be modulated by lipid rafts (Merixell Canals et al., 20I2). Since CXCR7 is expressed at low levels in normal cells and CXCLII (the ligand for CXCR7) binds to CXCR7 but does not activate GPCRmediated downstream pathways (Balabanian et al., 20I I), the interplay between CXCR4 and CXCR7 might affect the CXCR available at the membrane (Balabanian et al., 2005; Ehrlich et al., 2013). Thus, the balance between CXCR4/CXCR7 could determine the effects of CXCLI 2 on NPC proliferation after CXCLI 2 activation (Zhu et al., 20I2). In fact, CXCR7 is rapidly transferred to the plasma membrane, and it mediates CXCLI 2 endocytosis, as well as co-localizing with CXCR4 after exposing NPCs to CXCLI 2 (Zhu et al., 20I2).

CXCLI 2 protects NPCs from apoptotic challenges through the CXCR7 and CXCR4-mediated endocytotic signaling produced by the activation of ERKI/2 pathways (Zhu et al., 20I2). Activation of the CXCLI2-CXCR4 pathway is crucial for the migration of hematopoietic stem cells, various immune cells, and malignant tumor cells. However, some differences in their signaling pathways, in particular those involving the expression of the CXCR4 and CXCR7 receptors on the cell surface, could explain the differential influence of CXCLI 2. While CXCR4 has one classical ligand, CXCLI2, CXCR7 responds to both CXCLI 2 or Interferon-inducible T-cell alpha chemoattractant chemokine I-TAC (C-X-C motif) ligand, CXCLII. Thus, unlike CXCR4, CXCR7 competes with CXCLI2 and CXCLII (Burns et al., 2006), and therefore, CXCLI2-mediated responses could potentially be modulated by CXCLI I (Hartman et al., 2008). CXCLII is also called 
Interferon-gamma-inducible protein 9 (IP-9) that is chemotactic for activated $\mathrm{T}$ cells. This chemokine elicits its effects on its target cells by interacting with the cell surface chemokine receptor $\mathrm{CXCR} 3$, with a higher affinity than do the other ligands for this receptor, CXCL9 and CXCLIO (Hartmann et al., 2008).

CXCLI4, specifically binds to CXCR4 with a high affinity and it inhibits the CXCLI2-mediated chemotactic responses of human leukemia-derived cell line/CD34(+) hematopoietic progenitor cells. Thus, CXCLI 4 functions as a natural inhibitor of CXCLI 2 (Tanegashima et al., 20I3) and along with CXCR7, it may modulate stem cell maintenance and immune responses by regulating the CXCR4/CXCLI 2 responses (Tanegashima et al., 20I3).

Finally, CXCLI 2 can be regulated by hypoxia (Schioppa et al., 2003), and the level of CXCLI 2 expression and its binding affinity to particular receptors may decide the degree to which the CXCLI2/CXCR4 axis or the CXCLI2/CXCR7 system influences NPC proliferation (Virgintino et al., 20I3). In this context, the responsiveness of CXCR4 to the CXCLI2 gradient may be positively modulated or primed by several small molecules involved in inflammation, such as C3 complement cleavage fragments (Ratajczak et al., 2006; Wysoczynski et al., 2007). The molecular explanation for this phenomenon is based on the observation that C3 cleavage fragments enhance the incorporation of CXCR4 into membrane lipid rafts (Wysoczynski et al., 2005), thereby inducing dimerization and promoting the association between CXCR4 and downstream signaling molecules (Wysoczynski et al., 2007). Interestingly, high CXCLI 2 and C3 cleavage fragments levels in damaged tissues induce a chemoattractant gradient, which is responsible for CXCR4+ stem cell circulation (Wysoczynski et al., 2007). Indeed, the N-terminal end of CXCLI 2 appears to be responsible for a positive feedback loop that maintains a CXCLI 2 gradient that attracts neuroblasts from the SVZ into an injury site (Filippo et al., 2013).

\section{Effects of Cytokines on Chemokine Release by NPCs}

Cytokines and chemokines have been shown to alter NSC selfrenewal and progenitor cell differentiation, which is probably mediated by JAK/STAT signaling and transcriptional activation (Vitkovic et al., 2000; Hiroi and Ohmori, 2003; Das and Basu, 2008; Islam et al., 2009a). Soluble IL-6R (sIL-6R) binds IL-6 and promotes trans-signaling (Taga and Kishimoto, 1997; Jones, 2013). IL-6 also induces differentiation of cortical precursor cells into oligodendrocytes and can activate adult astrocytes (Kahn and De Vellis, 1994). IL-6 induces the differentiation of neural stem cells (NSCs) specifically into glutamate-responsive neurons and two morphological astroglia cell types. In fact, IL6-activated neurogenesis is induced by the MAPK/CREB (mitogen-activated protein kinase/cAMP response elementbinding protein) cascade (Islam et al., 2009a,b; Peng et al., $20 \mathrm{II}$ ). However, astrocyte differentiation is dependent on IL-6 family cytokine-mediated STAT3 (signal transducers and activators of transcription protein-3) activation (Taga and Kishimoto 1997; Taga and Fukuda, 2005).

Treatment of SVZ-derived NPCs with IFN $\gamma$ and TNF-alpha (alone or in combination) augmented CXCLI, CXCL9 and CCL2 chemokines but downregulated CCL19 (Turbic et al., 20II). Neuronal differentiation was promoted by CXCL9, CCL2, and CCL2I, although astrocyte and total oligodendrocyte differentiation was not affected. Conversely, IFN $\gamma, C X C L I, C X C L 9$, and CCL2 promoted oligodendrocyte maturation (Hiroi and Ohmori, 2003; Owens et al., 2005; Suyama et al., 2005; Lum et al., 2009; Conductier et al., 20l0; Turbic et al. 20II) and TNF-alpha also increased CXCR4 and CCR5 expression by astrocytes (Croitoru-Lamoury et al.,
2003). In addition, CCR7 was overexpressed in inflammatory conditions (Gomez-Nicola et al., 20 I0) while chronic exposure to LIF or CNTF altered the formation of NSC progeny and promoted NSC self-renewal, events inhibited by leptin (NakaiFutatsugi and Niwa, 2013).

\begin{tabular}{|c|c|}
\hline Chemokine/Cytokine & Effect on neural precursor cells \\
\hline IFN- $\gamma$ & $\begin{array}{l}\text { Reduces NSC proliferation and survival, } \\
\text { promotes differentiation and neurite } \\
\text { outgrowth (Wong et al., 2004; Bonaguidi et al., } \\
\text { 2005; Song et al., 2005; Lum et al., 2009) }\end{array}$ \\
\hline IL-4 & $\begin{array}{l}\text { Increases oligodendrocyte precursors (Suyama } \\
\text { et al., 2005; Butovsky et al., 2006; Guan et al., } \\
\text { 2008; Lum et al., 2009) }\end{array}$ \\
\hline TNF- $\alpha$ & $\begin{array}{l}\text { Inhibits neural progenitor differentiation } \\
\text { (Croitoru-Lamoury et al., 2003; Belmadani } \\
\text { et al., 2005) }\end{array}$ \\
\hline Leptin & $\begin{array}{l}\text { Inhibits neural progenitors differentiation (Nakai- } \\
\text { Futatsugi and Niwa, 20I3) }\end{array}$ \\
\hline IL-6/LIF & $\begin{array}{l}\text { Induces NSC self-renewal, as well as } \\
\text { differentiation into glutamatergic neurons or } \\
\text { oligodendrocytes (Bonaguidi et al., 2005; Bauer } \\
\text { and Patterson, 2006; Butovsky et al., 2006; } \\
\text { Oshima et al., 2007; Guan et al., 2008 Covey } \\
\text { and Levison, 2008) }\end{array}$ \\
\hline Leptin/MCP-I & $\begin{array}{l}\text { Affects oligodendroglial growth in the cortex } \\
\text { (Udagawa et al., 2006) and acts as a } \\
\text { chemotactic factor for neural precursors } \\
\text { (Widera et al., 2004) }\end{array}$ \\
\hline$C C L 2=M C P-I$ & $\begin{array}{l}\text { Promotes neuronal differentiation of SVZ neural } \\
\text { progenitors (Edman et al., 2008) }\end{array}$ \\
\hline CXCLI2 (SDF-I alpha) & $\begin{array}{l}\text { Chemotactic factor that also promotes the } \\
\text { survival and proliferation of adult NSCs, and } \\
\text { that induces proliferation through EGF } \\
\text { activation in NPCs (Zhu et al., 20I2). CXCLI } 2 \\
\text { mediates interactions between the } \\
\text { endothelium and glioblastoma (Rao et al., } \\
2012 \text { ) }\end{array}$ \\
\hline CNTF & $\begin{array}{l}\text { Promotes neurogenesis and stem cell self-renewal } \\
\text { (Shimazaki et al., 200I) }\end{array}$ \\
\hline CXCLI3/IL-8 & $\begin{array}{l}\text { Chemotaxis of endothelial cells (Weiss et al., } \\
\text { 20I0). }\end{array}$ \\
\hline $\mathrm{GRO} \alpha$ & $\begin{array}{l}\text { Regulates human embryonic stem cell self- } \\
\text { renewal and/or adoption of a neuronal fate. } \\
\text { Differentiation (Krtolica et al., 20II) }\end{array}$ \\
\hline
\end{tabular}

\section{Chemokines and Cell Therapy in CNS Disorders}

Hypoxic preconditioning of transplanted cells induces neurogenesis following cerebral ischemia. A number of engrafted-BMSCs induce chemotactic and trophic effects CXCLI 2 dependent levels for cell repair (Kucia et al., 2006; Brunner et al., 2009; Weiss et al., 2012). There is a connection between fibroblast growth factor receptor I (FGFR-I) activation and macrophage recruitment, which is dependent on CX3CLI levels (Reed et al., 20I2). In fact, macrophages promote fibroblast growth factor receptors (FGFR)-driven tumor cell migration and invasion in a CXCR2-dependent manner (Bohrer and Schwertfeger, 20I2). However, FGF has also been shown to have a protective effect against insults by exerting differential effects on neurons and glial cells. This suggests that EGF/FGF can also regulate NPC proliferation following insult, acting through regulatory chemokines (Sanders et al., 2000; Hadjipanayi et al., 20 I2; Itkin et al., 20I2).

Stem cells obtained from periodontal cells can respond to chemokines and $90 \%$ of periodontal cells can undergo neuronal differentiation, making them an accessible source of autologous human adult SCs and highlighting their potential for preventing CNS disorders (Widera et al., 2007). Transplantation of BMSCs may be a new approach for brain repair although their clinical use and the results of engraftment are still limited (Dezawa et al., 2005; Kaplan et al., 2007). Chemokines can direct BMSC migration toward damaged areas through chemotactic gradients and, since efficient transfection induces CXCR4 overexpression, BMSCs migrate rapidly toward 
CXCLI2 (Jin et al., 2006). The combined use of hematopoietic progenitor cells mobilized from bone marrow by granulocyte colony stimulating factor (GCSF) and AMD3 100 enhances chemotaxis in mouse models of Alzheimer's disease (Shin et al., $20 \mathrm{II}$ ). Thus, further studies should assess how chemokines contribute to the homing and migration of normal NPCs within the vascular niche so that this approach can be used in the context of neurodegenerative diseases. The neuroimmune interactions based on activation of the CXCR4/CXCLI2 cascade could enhance NPC migration in experimental models of CNS disease, thereby preventing cell death in rodent models of inflammatory or CNS disease, and potentially opening up the possibility of developing new therapies for cell repair (Whitney et al., 2009; Li et al., 20I2).

\section{Conclusion and Concluding Remarks}

This review presents evidence showing that CXCR4/CXCLI2 signaling contributes to NPC migration to areas of CNS damage. The homing cascade that drives cell adhesion to brain endothelial cells and transendothelial migration is important for cell repair (Cui et al., 2007). NPCs in the adult SVZ are associated with the ependymal and vasculature niches that regulate stem cell self-renewal and differentiation. There are several cell types in the SVZ, from activated Type B stem cells to the transit-amplifying type $C$ cells that express EGFR (Abhold et al., 20I2) and these are most strongly associated with vascular cells (Miller and Gauthier-Fisher, 2009).

Clearly, much remains to be learnt about how CXCR4/ CXCR7 activity controls NPC recruitment to damaged areas of the CNS. However, some studies have shown that classic signaling pathways are involved in neuronal migration, particularly since CXCLI2 binding to CXCR4 can mediate $G$ activation and induce intracellular signaling in NPCs (van Biesen et al., 1996; Bajetto et al., 1999). Consequently, the activation of 3 PI-kinase/Akt by CXCLI 2 mediates NPC proliferation (CXCR4+) (Ni et al., 2004), and regulates Akt-I and FOXO3a phosphorylation (Wu et al., 2009; Holgado et al., 20I3). The JAK/STAT or ERKI $/ 2$ cascades mediated CXCLI 2 proliferative effects in NPCs in vitro, along with other signaling pathways.

$\mathrm{NO}$, EPO and metalloprotease activity (MMP2/9 or ADAMI7), or CXCLI2 availability, regulate CXCR4/CXCR7 chemokine function in NPCs, since CXCR7 expression was found to be regulated by the membrane levels of CXCR4 (Wang et al., 2008). On the other hand, EPO induces NPC migration via the CXCR4/CXCLI 2 axis, while the NO donor DETA-NONOate promotes SVZ neuroblast cell migration through CXCLI 2 and Ang I in the SVZ, supporting their role in CNS repair (Cui et al., 2007). In addition, metalloproteases control stem cells trafficking (Son et al., 2006), since MMP-2 regulates chemotaxis through CXCLI 2 given that MMP-2 activation cleaves CXCLI 2 into the truncated CXCLI 2 (SDFI alha) (1-56) neurotoxic form that impedes progenitor proliferation and migration.

Collectively, these findings support the notion that CXCR4/ CXCL 12 signaling drives NPC migration to initiate endogenous stem cell-based tissue repair and to regulate the capacity to recruit new neuroblasts from the SVZ/RMS toward damaged areas of the CNS. In this context, CXCLI 2 can provide a bidirectional signal acting, as a chemoattractant or as an inducer of NPC migration, depending on its concentration. Consequently, understanding the signaling pathways downstream of CXCR4 will be crucial to elucidating how neuroprotectants prevent cell death in the CNS. In this context, NO, MPP2/9, and CXCLI 2 availability are key factors that regulate homing and repair responses in damaged tissues. Thus, CXCR4 activation by neuroprotectants or new NO donors may possibly prevent CNS damage. However, the carbamylated derivative erythropoietin (cEpo) offers hematopoietic tissue protection without an increase in hematocrit, and its clinical efficacy in inducing the homing of progenitor cells via the CXCR-4/CXCLI 2 axis remains to be confirmed.

Since metalloprotease activation can be induced in CNS pathologies but may also contribute to neurogenesis, inhibitors of MMPs could regulate the shedding of chemokines. In fact, MMP-2, ADAMI7, and ADAM I0 can cleave CXCLI 2 into a neurotoxic form. Consequently, the use of inhibitors of sheddases and MMP blockers could blunt the inflammatory responses mediated by chemokines and cytokines in the acute phase of cell death. However, the use of MMP 2/9 inhibitors is likely to be less useful in promoting cell repair and axonal regeneration. Further studies will be necessary to clarify the possible therapeutic influence of MMP inhibitors on chemokine levels in neurodegenerative diseases

In conclusion, the CXCR4/CXCLI 2 axis emerges as a target for neuroprotectants in CNS pathologies.

This review has attempted to provide an update on the neuroimmune interactions by which chemokines regulate NPC migration. Finally, CXCLI 2 based therapy could stimulate neuroblast recruitment and enhance survival of new formed neurons. Thus, neuroprotectants that activate CXCR4 signaling could possibly prevent apoptosis and induce repair in animal models of HIV-I neuropathogenesis, multiple sclerosis, cerebral ischemia, Alzheimer or trauma, among other pathological situations. Although there is promising data on CXCR4/CXCLI 2 and CNS repair, further studies will be necessary before translating chemokine studies into clinical therapies. Nevertheless, beneficial clinical effects of AMD3 100 (a CXCR4 chemokine blocker) plus GCSF synergic treatment to mobilize stem cell trafficking by CD34+ cells have already been observed in pediatric patients after 2 to 3 cycles of apheresis, without clinical complications (Hong et al., 2012).

\section{Acknowledgements}

We acknowledge the financial support of the Comisión Interministerial de Ciencia y Tecnologíä (Grant SAF 20123 I27) and the "Ramon y Cajal" programme (RyC 2008-0258 to JJM and RyC 2010-0625I to B.C). We also thank Fundación Ramón Areces for its institutional support of the "Centro de Biología Molecular Severo Ochoa". We thank Ma Pilar González (PhD) and Juan Francisco Martinez for critical reading of the manuscript.

\section{Literature Cited}

Abhold EL, Kiang A, Rahimy E, Kuo SZ, Wang-Rodriguez J, Lopez JP, Blair KJ, Yu MA, Haas M, Brumund KT, Altuna X, Patel A, Weisman RA, Ongkeko WM. 2012. EGFR kinase promotes acquisition of stem cell-like properties: A potential therapeutic target in head and neck squamous cell carcinoma stem cells. PLoS One 7:e32459.

Aboody KS, Brown A, Rainov NG, Bower KA, Liu S, Yang W, Small JE, Herrlinger U, Ourednik V, Black PM, Breakefield XO, Snyder EY. 2000. Neural stem cells display extensive tropism for pathology in adult brain: Evidence from intracranial gliomas. PNAS 7:|2846-|285|.

Aguirre A, Rizvi TA, Ratner N, Gallo V. 2005. Overexpression of the epidermal growth factor receptor confers migratory properties to nonmigratory postnatal neural progenitors. J Neurosci 25:11092-111106.

Ahr B, Denizot M, Robert-Hebmann V, Brelot A, Biard-Piechaczyk M. 2005. Identification of the cytoplasmic domains of CXCR4 involved in Jak2 and STAT3 phosphorylation. J Biol Chem 280:6692-6700.

Aicher A, Heeschen C, Mildner-Rihm C, Urbich C, Ihling C, Technau-Ihling K, Zeiher AM, Dimmeler S. 2003. Essential role of endothelial nitric oxide synthase for mobilization of stem and progenitor cells. Nat Med 9:1370-1376.

Aiuti A, Webb IJ, Bleul C, Springer T, Gutierrez-Ramos JC. 1997. The chemokine SDF-I is a chemoattractant for human CD34+ hematopoietic progenitor cells and provides a new mechanism to explain the mobilization of CD34+ progenitors to peripheral blood. J Exp Med 185:III-120.

Altman J, Das GD. 1965. Post-natal origin of microneurones in the rat brain. Nature 207:953-956.

Amantea D, Nappi G, Bernardi G, Bagetta G, Corasaniti MT 2009. Post-ischemic brain damage: pathophysiology and role of inflammatory mediators. FEBS J 276:13-26.

Amara A, Lorthioir O, Valenzuela A, Magerus A, Thelen M, Montes M, Virelizier JL, Delepierre M, Baleux F, Lortat-Jacob H, Arenzana-Seisdedos F. 1999. Stromal cell-derived factor-I alpha associates with heparan sulfates through the first beta-strand of the chemokine. J Biol Chem 274:23916-23925. 
Andreu-Agullo C, Maurin T, Thompson CB, Lai EC. 20II. Ars2 maintains neural stem-cell identity through direct transcriptional activation of Sox2. Nature 481:195-198. Arvidsson A, Collin T, Kirik D, Kokaia Z, Lindvall O. 2002. Neuronal replacement from endogenous precursors in the adult brain after stroke. Nat Med 8:963-970.

Asahi M, Wang X, Mori T, Sumii T, Jung JC, Moskowitz MA, Fini ME, Lo EH. 200I. Effects of matrix metalloproteinase-9 gene knock-out on the proteolysis of blood-brain barrier and white matter components after cerebral ischemia. J Neurosci 21:7724-7732

Asensio VC, Campbell IL. 1999. Chemokines in the CNS: Plurifunctional mediators in diverse states. Trends Neurosci 22:504-512.

Avasarala JR, Konduru SS. 2005. Recombinant erythropoietin down-regulates IL-6 and CXCR4 genes in TNF-alpha-treated primary cultures of human microvascular endothelial cells: Implications for multiple sclerosis. J Mol Neurosci 25:183-189.

Bagri A, Gurney T, He X, Zou YR, Littman DR, Tessier-Lavigne M, Pleasure SJ. 2002. The chemokine SDFI regulates migration of dentate granule cells. Development 129:4249_ 4260.

Bajetto A, Bonavia R, Barbero S, Piccioli P, Costa A, Florio T, Schettini G. 1999. Glial and neuronal cells express functional chemokine receptor CXCR4 and its natural ligand stromal cell-derived factor I. J Neurochem 73:2348-2357.

Bakondi B, Shimada IS, Peterson BM, Spees JL. 20II. SDF-I $\alpha$ secreted by human CDI33derived multipotent stromal cells promotes neural progenitor cell survival through CXCR7. Stem Cells Dev. 20:1021-1029.

Balabanian K, Lagane B, Infantino S, Chow KY, Harriague J, Moepps B, Arenzana-Seisdedos F, Thelen M, Bachelerie F. 2005. The chemokine SDF- I/CXCLI2 binds to and signals through the orphan receptor RDCI in T lymphocytes. J Biol Chem 280:35760-35766.

Banisadr G, Bhattacharyya BJ, Belmadani A, Izen SC, Ren D, Tran PB, Miller RJ. 20II. The chemokine BRAK/CXCLI4 regulates synaptic transmission in the adult mouse dentate gyrus stem cell niche. J Neurochem II9:I173-1182.

Barkho B, Zhao X. 2010. Neural stem cell migration: Roles of chemokines and proteases. In: Jin K, editor. Adult Neurogenesis and Central Nervous System Diseases. Research Signpost. Pp 65-90.

Barkho BZ, Munoz AE, Li X, Li L, Cunningham LA, Zhao X. 2008. Endogenous matrix metalloproteinase (MMP)-3 and MMP-9 promote the differentiation and migration of adult neural progenitor cells in response to chemokines. Stem Cells 26 : 3139-3149.

Bauer S, Patterson PH. 2006. Leukemia inhibitory factor promotes neural stem cell selfrenewal in the adult brain. J Neurosci 26:12089-12099.

Bauer S. 2009. Cytokine control of adult neural stem cells. Ann NY Acad Sci | I53:48-56.

Belmadani A, Tran PB, Ren D, Assimacopoulos S, Grove EA, Miller RJ. 2005. The chemokine

stromal cell-derived factor-I regulates the migration of sensory neuron progenitors. J Neurosci 25:3995-4003.

Belmadani A, Tran PB, Ren D, Miller RJ. 2006. Chemokines regulate the migration of neural progenitors to sites of neuroinflammation. J Neurosci 26:3|82-319|.

Ben-Hur T, Ben-Menachem O, Furer V, Einstein O, Mizrachi-Kol R, Grigoriadis N. 2003. Effects of proinflammatory cytokines on the growth, fate, and motility of multipotential neural precursor cells. Mol Cell Neurosci 24:623-631.

Berger O, Li G, Han SM, Paredes M, Pleasure SJ. 2007. Expression of SDF-I and CXCR4 during reorganization of the postnatal dentate gyrus. Dev Neurosci 29:48-58.

Bernier PJ, Bedard A, Vinet J, Levesque M, Parent A. 2002. Newly generated neurons in the amygdala and adjoining cortex of adult primates. PNAS 99: I | 464-I| 469.

Bhattacharyya BJ, Banisadr G, Jung H, Ren D, Cronshaw DG, Zou Y, Miller RJ. 2008. The chemokine stromal cell-derived factor-I regulates GABAergic inputs to neural progenitors in the postnatal dentate gyrus. J Neurosci 28:6720-6730.

Birkenkamp KU, Essafi A, van der Vos KE, da Costa M. Hui RC. Holstege F, Koenderman L, Lam EW, Coffer PJ. 2007. FOXO3a induces differentiation of Bcr-Abl-transformed cells through transcriptional down-regulation of IdI. J Biol Chem 282:22I I-2220.

Bohrer LR, Schwertfeger KL. 20I2. Macrophages promote fibroblast growth factor receptor-driven tumor cell migration and invasion in a CXCR2-dependent manner. Mol Cancer Res 10:1294-1305.

Boldajipour B, Mahabaleshwar H, Kardash E, Reichman-Fried M, Blaser H, Minina S, Wilson $\mathrm{D}, \mathrm{Xu}$ Q, Raz E. 2008. Control of chemokine-guided cell migration by ligand sequestration. Cell 132:463-473.

Bonaguidi MA, McGuire T, Hu M, Kan L, Samanta J, Kessler JA. 2005. LIF and BMP signaling generate separate and discrete types of GFAP-expressing cells. Development 132:55035514.

Bonaguidi MA, Peng CY, McGuire T, Falciglia G, Gobeske KT, Czeisler C, Kessler JA. 2008. Noggin expands neural stem cells in the adult hippocampus. J Neurosci 28:9194-9204.

Bondeva T, Pirola L, Bulgarelli-Leva G, Rubio I, Wetzker R, Wymann MP. 1998. Bifurcation of lipid and protein kinase signals of PI3Kgamma to the protein kinases PKB and MAPK. Science 282:293-296.

Bonecchi R, Galliera E, Borroni EM, Corsi MM, Locati M, Mantovani A. 2009. Chemokines and chemokine receptors: An overview. Front Biosci 14:540-55I.

Boneva NB, Yamashima T. 2012. New insights into "GPR40-CREB interaction in adult neurogenesis" specific for primates. Hippocampus 22:896-905.

Borrell V, Marín O. 2006. Meninges control tangential migration of hem-derived

Cajal-Retzius cells via CXCLI2/CXCR4 signaling. Nat Neurosci 9:1284-1293.

Brettschneider J, Widl K, Ehrenreich H, Riepe M, Tumani H. 2006. Erythropoietin in the cerebrospinal fluid in neurodegenerative diseases. Neurosci Lett 404:347-35I.

Brunner S, Winogradow J, Huber BC, Zaruba MM, Fischer R, David R, Assmann G, Herbach N, Wanke R, Mueller-Hoecker J, Franz WM. 2009. Erythropoietin administration after myocardial infarction in mice attenuates ischemic cardiomyopathy associated with enhanced homing of bone marrow-derived progenitor cells via the CXCR-4/SDF-I axis. FASEB ] 23:35I-36I.

Burns JM, Summers BC, Wang Y, Melikian A, Berahovich R, Miao Z, Penfold ME, Sunshine MJ, Littman DR, Kuo CJ, Wei K, McMaster BE, Wright K, Howard MC, Schall TJ. 2006. A novel chemokine receptor for SDF-I and I-TAC involved in cell survival, cell adhesion, and tumor development. Jxp Med 203:2201-2213. Epub2006 Aug 28.

Butovsky O, Ziv Y, Schwartz A, Landa G, Talpalar AE, Pluchino S, Martino G, Schwartz M. 2006. Microglia activated by IL-4 or IFN-gamma differentially induce neurogenesis and oligodendrogenesis from adult stem/progenitor cells. Mol Cell Neurosci 31:149-160.

Bye N, Turnley AM, Morganti-Kossmann MC. 2012. Inflammatory regulators of redirected neural migration in the injured brain. Neurosignals 20:132-146.

Cai Z, Semenza GL. 2004. Phosphatidylinositol-3-kinase signaling is required for erythropoietin-mediated acute protection against myocardial ischemia/reperfusion injury. Circulation 109:2050-2053.

Canals M, Scholten DJ, de Munnik S, Han MK, Smit MJ, Leurs R. 2012. Ubiquitination of CXCR7 controls receptor trafficking. PLoS One 7:e34192.

Canete-Soler R, Gui YH, Linask KK, Muschel RJ. 1995b. Developmental expression of MMP9 (gelatinase B) mRNA in mouse embryos. Dev Dyn 204:30-40.
Canete-Soler R, Gui YH, Linask KK, Muschel RJ. 1995b. MMP-9 (gelatinase B) mRNA is expressed during mouse neurogenesis and may be associated with vascularization. Brain Res Dev Brain Res 88:37-52.

Carbajal KS, Schaumburg C, Strieter R, Kane J, Lane TE. 2010. Migration of engrafted neural stem cells is mediated by CXCLI2 signaling through CXCR4 in a viral model of multiple sclerosis. PNAS 107: I 1068-11073.

Casoni F, Hutchins BI, Donohue D, Fornaro M, Condie BG, Wray S. 2012. SDF and GABA interact to regulate axophilic migration of GnRH neurons. J Cell Sci I25: 5015-5025.

Chalasani SH, Baribaud F, Coughlan CM, Sunshine MJ, Lee VM, Doms RW, Littman DR, Raper JA. 2003a. The chemokine stromal cell-derived factor-I promotes the survival of embryonic retinal ganglion cells. J Neurosci 23:460I-46I2.

Chalasani SH, Sabelko KA, Sunshine MJ, Littman DR, Raper JA. 2003b. A chemokine, SDF-I, reduces the effectiveness of multiple axonal repellents and is required for normal axon pathfinding. J Neurosci 23:1360-1371.

Chambon F, Merlin E, Rochette E, Pereira B, Halle P, Deméocq F, Kanold J. 2013. Mobilization of hematopoietic stem cells by plerixafor alone in children: A sequential Bayesian trial. Transfus Apher Sci 49:453-458.

Chamorro ME, Wenker SD, Vota DM, Vittori DC, Nesse AB. 20I3. Signaling pathways of cell proliferation are involved in the differential effect of erythropoietin and its carbamylated derivative. Biochim Biophys Acta 1833:1960-1968.

Chang F, Lee JT, Navolanic PM, Steelman LS, Shelton JG, Blalock WL, Franklin RA, McCubrey A. 2003. Involvement of PI3K/Akt pathway in cell cycle progression, apoptosis, and neoplastic transformation: a target for cancer chemotherapy. Leukemia 17:590-603.

Chaturvedi M, Kaczmarek L. 2013. MMP-9 Inhibition: A Therapeutic Strategy in Ischemic Stroke. Mol Neurobiol Mol Neurobiol.

Chen ZY, Asavaritikrai P, Prchal JT, Noguchi CT. 2007. Endogenous erythropoietin signaling is required for normal neural progenitor cell proliferation. J Biol Chem 282:25875-25883.

Chen J, Li Y, Wang L, Zhang Z, Lu D, Lu M, Chopp M. 200I. Therapeutic benefit of intravenous administration of bone marrow stromal cells after cerebral ischemia in rats. Stroke 32:1005-1011.

Chen J, Li Y, Zhang R, Katakowski M, Gautam SC, Xu Y, Lu M, Zhang Z, Chopp M. 2004. Combination therapy of stroke in rats with a nitric oxide donor and human bone marrow stromal cells enhances angiogenesis and neurogenesis. Brain Res 1005:21-28.

Chen E, Xu D, Lan X, Jia B, Sun L, Zheng JC, Peng HA. 2013. Novel role of the STAT3 pathway in brain inflammation-induced human neural progenitor cell differentiation. Curr Mol Med 13:1474-1484

Chen J, Zacharek A, Zhang C, Jiang H, Li Y, Roberts C, Lu M, Kapke A, Chopp M. 2005. Endothelial nitric oxide synthase regulates brain-derived neurotrophic factor expression and neurogenesis after stroke in mice. J Neurosci 25:2366-2375.

Cherla RP, Ganju RK. 200 I. Stromal cell-derived factor I alpha-induced chemotaxis in T cells is mediated by nitric oxide signaling pathways. J Immunol 166:3067-3074.

Choi YS, Cho HY, Hoyt KR, Naegele JR, Obrietan K. 2008. IGF-I receptor-mediated ERK/ MAPK signaling couples status epilepticus to progenitor cell proliferation in the subgranular layer of the dentate gyrus. Glia 56:79|-800.

Chong ZZ, Maiese. K. 2007. Erythropoietin involves the phosphatidylinositol 3-kinase pathway, 14-3-3 protein, and FOXO3a nuclear trafficking to preserve endothelial cell integrity. Br J Pharmacol 150:14-13.

Christie KJ, Turnley AM. 2013. Regulation of endogenous neural stem/progenitor cells for neural repair-factors that promote neurogenesis and gliogenesis in the normal and damaged brain. Front Cell Neurosci. 6:70.

Chu H, Zhou H, Liu Y, Liu X, Hu Y, Zhang. 2007. Functional expression of CXC chemokine recepter-4 mediates the secretion of matrix metalloproteinases from mouse hepatocarcinoma cell lines with different lymphatic metastasis ability. Int J Biochem Cell Biol 39:197-205.

Chute JP. 2006. Stem cell homing. Curr Opin Hematol 13:399-406.

Conductier G, Blondeau N, Guyon A, Nahon JL, Rovere C. 20I0. The role of monocyte chemoattractant protein MCPI/CCL2 in neuroinflammatory diseases. J Neuroimmunol 224:93-100.

Coremans V, Ahmed T, Balschun D, D'Hooge R, DeVriese A, Cremer J, Antonucci F, Moons M, Baekelandt V, Reumers V, Cremer H, Eisch A, Lagace D, Janssens T, Bozzi Y, Caleo M, Conway EM. 2010. Impaired neurogenesis, learning and memory and low seizure threshold associated with loss of neural precursor cell survivin. BMC Neurosci II:2.

Coskun V, Luskin MB. 2002. Intrinsic and extrinsic regulation of the proliferation and differentiation of cells in the rodent rostral migratory stream. J Neurosci Res 69: 795-802.

Costantini S, Raucci R, De Vero T, Castello G, Colonna G. 2013. Common structural interactions between the receptors CXCR3, CXCR4 and CXCR7 complexed with their natural ligands, CXCLII and CXCLI2, by a modeling approach. Cytokine 64:316-32I. Epub 2013 Jun 15

Covey MV, Levison SW. 2007. Leukemia inhibitory factor participates in the expansion of neural stem/progenitors after perinatal hypoxia/ischemia. Neuroscience 148:50I-509.

Croitoru-Lamoury ], Guillemin G], Boussin FD, Mognetti B, Gigout LI, Chéret A, Vaslin B, Le Grand R, Brew B], Dormont D. 2003. Expression of chemokines and their receptors in human and simian astrocytes: Evidence for a central role of TNF alpha and IFN gamma in CXCR4 and CCR5 modulation. Glia 41:354-370.

Cubelos B, Sebastián-Serrano A, Beccari L, Calcagnotto ME, Cisneros E, Kim S, Dopazo A Alvarez-Dolado M, Redondo JM, Bovolenta P, Walsh CA, Nieto M. 2010. Cuxl and Cux2 regulate dendritic branching, spine morphology, and synapses of the upper layer neurons of the cortex. Neuron 66:523-535.

Cubelos B, Sebastián-Serrano A, Kim S, Redondo JM, Walsh C, Nieto M. 2008. Cux-I and Cux-2 control the development of Reelin expressing cortical interneurons. Dev Neurobiol 68:917-925.

Cui X, Chen J, Zacharek A, Li Y, Roberts C, Kapke A, Savant-Bhonsale S, Chopp M. 2007. Nitric oxide donor upregulation of stromal cell-derived factor-I/chemokine (CXC motif) receptor 4 enhances bone marrow stromal cell migration into ischemic brain after stroke. Stem Cells 25:2777-2785.

Daniel D, Rossel M, Seki T, König N. 2005. Stromal cell-derived factor-I (SDF-I) expression in embryonic mouse cerebral cortex starts in the intermediate zone close to the pallialsubpallial boundary and extends progressively towards the cortical hem. Gene Expr Patterns 5:317-322.

Dar A, Goichberg P, Shinder V, Kalinkovich A, Kollet O, Netzer N, Margalit R, Zsak M, Nagler A, Hardan I, Resnick I, Rot A, Lapidot T. 2005. Chemokine receptor CXCR4 dependent internalization and resecretion of functional chemokine SDF-I by bone marrow endothelial and stromal cells. Nat Immunol 6:1038-1046.

Das S, Basu A. 2008. Inflammation: A new candidate in modulating adult neurogenesis. J Neurosci Res 86:1199-1208. 
Decimo I, Bifari F, Krampera M, Fumagalli G. 2012. Neural stem cell niches in health and diseases. Curr Pharm Des 18:1755-1783.

Delgado-Martin C, Escribano C, Pablos JL, Riol-Blanco L, Rodriguez-Fernandez JL. 2011 Chemokine CXCLI 2 uses CXCR4 and a signaling core formed by bifunctional Akt, extracellular signal-regulated kinase (ERK) I/2, and mammalian target of rapamycin complex I (mTORCI) proteins to control chemotaxis and survival simultaneously in mature dendritic cells. J Biol Chem 286:37222-37236.

Dempsey RJ, Kalluri HS. 2007. Ischemia-induced neurogenesis: Role of growth factors. Neurosurg Clin N Am 18:183-190.

Dezawa M, Hoshino M, Nabeshima Y, Ide C. 2005. Marrow stromal cells: Implications in health and disease in the nervous system. Curr Mol Med 5:723-732.

Dziembowska M, Tham TN, Lau P, Vitry S, Lazarini F, Dubois-Dalcq M. 2005. A role for CXCR4 signaling in survival and migration of neural and oligodendrocyte precursors. Glia 50:258-269.

Edman LC, Mira H, Arenas E. 2008. The beta-chemokines CCL2 and CCL7 are two novel differentiation factors for midbrain dopaminergic precursors and neurons. Exp Cell Res $314: 2123-2130$

Ehrlich A, Ray P, Luker KE, Lolis EJ, Luker GD. 2013. Allosteric peptide regulators of chemokine receptors CXCR4 and CXCR7. Biochem Pharmacol 86:1263-I27I.

Ekdahl CT, Claasen JH, Bonde S, Kokaia Z, Lindvall O. 2003. Inflammation is detrimental for neurogenesis in adult brain. PNAS 100:13632-13637.

Fallon J, Reid S, Kinyamu R, Opole I, Opole R, Baratta J, Korc M, Endo TL, Duong A, Nguyen G, Karkehabadhi M, Twardzik D, Patel S, Loughlin S. 2000. In vivo induction of massive proliferation, directed migration, and differentiation of neural cells in the adult mammalian brain. PNAS 97:14686-|4691.

Fiala M, Avagyan H, Merino JJ, Bernas M, Valdivia J, Espinosa-Jeffrey A, Witte M, Weinand M. 20I2. Chemotactic and mitogenic stimuli of neuronal apoptosis in patients with medically intractable temporal lobe epilepsy. Pathophysiology 20:59-69.

Filippo TR, Galindo LT, Barnabe GF, Ariza CB, Mello LE, Juliano MA, Juliano L, Porcionatto MA. 2013. CXCLI2 N-terminal end is sufficient to induce chemotaxis and proliferation of neural stem/progenitor cells. Stem Cell Res II:913-925

Foshay KM, Gallicano GI. 2008. Regulation of Sox2 by STAT3 initiates commitment to the neural precursor cell fate. Stem Cells Dev 17:269-278.

Gage FH, Coates PW, Palmer TD, Kuhn HG, Fisher LJ, Suhonen JO, Peterson DA, Suhr ST, Ray J. 1995. Survival and differentiation Cell Stem Cell Neural Progenitors of adult neuronal progenitor cells transplanted to the adult brain. PNAS 92:1।879-1।883.

Gao D, Ning N, Niu X, Dang Y, Dong X, Wei J, Zhu C. 2012. Erythropoietin treatment in patients with acute myocardial infarction: a meta-analysis of randomized controlled trials. Am Heart J 164:715-727.

Gensel JC, Kigerl KA, Mandrekar-Colucci SS, Gaudet AD, Popovich PG. 20I2. Achieving CNS axon regeneration by manipulating convergent neuro-immune signaling Cell Tissue Res 349:201-213.

Giusto $E$, Donegà M, Cossetti C, Pluchino S. 2013. Neuro-immune interactions of neural stem cell transplants: From animal disease models to human trials. Exp Neurol S0OI44886:00092-00097.DOI: 10.1016/j.expneurol.2013.03.009.

Goings GE, Sahni V, Szele FG. 2004. Migration patterns of subventricular zone cells in adult mice change after cerebral cortex injury. Brain Res 996:213-226.

Gomez-Nicola D, Pallas-Bazarra N, Valle-Argos B, Nieto-Sampedro M. 2010. CCR7 is expressed in astrocytes and upregulated after an inflammatory injury J Neuroimmunol 227:87-92.

Gong X, He X, Qi L, Zuo H, Xie Z. 2006. Stromal cell derived factor-I acutely promotes neural progenitor cell proliferation in vitro by a mechanism involving the ERK I/2 and $\mathrm{PI}$ 3K signal pathways. Cell Biol Int 30:466-47I.

Gonzalez-Perez O, Jauregui-Huerta F, Yadira Galvez-Contreras A. 2010. Immune system modulates the function of adult neural stem cells. Curr Immunol Rev 6:167-173.

Gordon RJ, McGregor AL, Connor B. 2009. Chemokines direct neural progenitor cell migration following striatal cell loss. Mol Cell Neurosci 41:219-232.

Gould E, Reeves AJ, Graziano MS, Gross CG. 1999. Neurogenesis in the neocortex of adult primates. Science 286:548-552.

Gould E. 2007. How widespread is adult neurogenesis in mammals. Nat Rev Neurosci 8:48I488 .

Guan Y, Jiang Z, Ciric B, Rostami AM, Zhang GX. 2008. Upregulation of chemokine receptor expression by IL-10/L-4 in adult neural stem cells. Exp Mol Pathol 85:232-236.

Guillermet-Guibert J, Bjorklof K, Salpekar A, Gonella C, Ramadani F, Bilancio A, Meek S, Smith AJ, Okkenhaug K, Vanhaesebroeck B. 2008. The pl IObeta isoformof phosphoinositide 3-kinase signals downstream of $\mathrm{G}$ protein-coupled receptors and is functionally redundant with PII0gamma. PNAS 105:8292-8297.

Guo Z, Cai S, Fang R, Chen H, Du J, Tan Y, Ma W, Hu H, Cai S, Liu Y. 2007. The synergistic effects of CXCR4 and EGFR on promoting EGF-mediated metastasis in ovarian cancer cells. Colloids Surf, B Biointerfaces 60:I-6.

Hadjipanayi E, Cheema U, Hopfner U, Bauer A, Machens HG, Schilling AF. 20I2. Injectable system for spatio-temporally controlled delivery of hypoxia-induced angiogenic signalling. J Control Release 161:852-860.

Hagberg H, Mallard C. 2005. Effect of inflammation on central nervous system development and vulnerability. Curr Opin Neurol 18:117-123.

Hallbergson AF, Gnatenco C, Peterson DA. 2003. Neurogenesis and brain injury: Managing a renewable resource for repair. J Clin Invest II2:1 I 28-1 I33.

Hartmann TN, Grabovsky V, Pasvolsky R, Shulman Z, Buss EC, Spiegel A, Nagler A, Lapido T, Thelen M, Alon R. 2008. A crosstalk between intracellular CXCR7 and CXCR4 involved in rapid CXCLI2-triggered integrin activation but not in chemokine-triggered motility of human T lymphocytes and CD34+ cells. Leukoc Biol 84: I 130-II40.

Hassani Z, O'Reilly J, Pearse Y, Stroemer P, Tang E, Sinden J, Price J, Thuret S. 2012. Human neural progenitor cell engraftment increases neurogenesis and microglial recruitment in the brain of rats with stroke. PLoS One 7e50444.

Hattermann K, Ludwig A, Gieselmann V, Held-Feindt J, Mentlein R. 2008. The chemokine CXCLI6 induces migration and invasion of glial precursor cells via its receptor CXCR6. Mol Cell Neurosci 39:133-141.

Hiroi M, Ohmori Y. 2003. The transcriptional coactivator CREB-binding protein cooperates with STATI and NF-kappa B for synergistic transcriptional activation of the CXC ligand 9/ monokine induced by interferon-gamma gene. J Biol Chem 278:65I-660.

Holgado BL, Martínez-Muñoz L, Sánchez-Alcañiz JA, Lucas P, Pérez-García V, Pérez G, Rodríguez-Frade JM, Nieto M, Marín O, Carrasco YR, Carrera AC, Alvarez-Dolado M, Mellado M. 2013. CXCLI2-mediated murine neural progenitor cell movement require PI3K $\beta$ activation. Mol Neurobiol 48:217-23I.

Hong KT, Kang HJ, Kim NH, Kim MS, Lee JW, Kim H, Park KD, Shin HY, Ahn HS. 2012. Successful mobilization using a combination of plerixafor and G-CSF in pediatric patients who failed previous chemomobilization with G-CSF alone and possible complications of the treatment. J Hematol Oncol 5:14.DOI: 10.1186/1756-8722. llieva M, Dufva M. 2013. SOX2 and OCT4 mRNA-expressing cells, detected by molecula beacons, localize to the center of neurospheres during differentiation. PLoS One 8: e73669.DOI: 10.1371/journal.pone.0073669. eCollection 2013.

Imitola J, Raddassi K, Park KI, Mueller FJ, Nieto M, Teng YD, Frenkel D, Li J, Sidman RL, Walsh CA, Snyder EY, Khoury SJ. 2004. Directed migration of neural stem cells to sites of CNS injury by the stromal cell-derived factor Ialpha/CXC chemokine receptor 4 pathway. PNAS 101:18117-18122.

Islam O, Gong X, Rose-John S, Heese K. 2009a. Interleukin-6 and neural stem cells: More than gliogenesis. Mol Biol Cell 20:188-199.

slam O, Loo TX, Heese K. 2009b. Brain-derived neurotrophic factor (BDNF) has proliferative effects on neural stem cells through the truncated TRK-B receptor, MAP kinase, AKT, and STAT-3 signaling pathways. Curr Neurovasc Res 6:42-53.

Itkin T, Ludin A, Gradus B, Gur-Cohen S, Kalinkovich A, Schajnovitz A, Ovadya Y, Kollet O, Canaani J, Shezen E, Coffin DJ, Enikolopov GN, Berg T, Piacibello W, Hornstein E, Lapidot T. 2012. FGF-2 expands murine hematopoietic stem and progenitor cells via proliferation of stromal cells, c-Kit activation, and CXCLI2 down-regulation. Blood I20:1843-1855 Itoh T, Satou T, Ishida H, Nishida S, Tsubaki M, Hashimoto S, Ito H. 2009. The relationship between SDF-I alpha/CXCR4 and neural stem cells appearing in damaged area after traumatic brain injury in rats. Neurol Res 31:90-102.

anowska-Wieczorek A, Marquez LA, Dobrowsky A, Ratajczak MZ, Cabuhat ML. 2000. Differential MMP and TIMP production by human marrow and peripheral blood CD34(+) cells in response to chemokines. Exp Hematol 28:1274-1285.

Ji JF, He BP, Dheen ST, Tay SS. 2004a. A Expression of chemokine receptors in neural progenitor cells isolated from the subventricular zone of the adult rat brain. Neurosci Lett 355:236-240

Ji JF, He BP, Dheen ST, Tay SS. 2004b. Interactions of chemokines and chemokine receptors mediate the migration of mesenchymal stem cells to the impaired site in the brain after hypoglossal nerve injury. Stem Cells 22:4I5-427.

Jin DK, Shido K, Kopp HG, Petit I, Shmelkov SV, Young LM, Hooper AT, Amano H, Avecilla ST, Heissig B, Hattori K, Zhang F, Hicklin DJ, Wu Y, Zhu Z Dunn A, Salari H, Werb Z Hackett NR, Crystal RG, Lyden D, Rafii S. 2006. Cytokine-mediated deployment of SDF-I induces revascularization through recruitment of CXCR4+ hemangiocytes. Nat Med 12:557-567.

Jin K, Sun Y, Xie L, Mao XO, Childs J, Peel A, Logvinova A, Banwait S, Greenberg DA. 2005. Comparison of ischemia-directed migration of neural precursor cells after intrastriatal, intraventricular, or intravenous transplantation in the rat. Neurobiol Dis 18:366-374.

Jo DY, Rafii S, Hamada T, Moore MA. 2000. Chemotaxis of primitive hematopoietic cells in response to stromal cell-derived factor-I. J Clin Invest 105:I0I-III.

Jones B. 20 I 3. Inflammation: Fetal bone growth directly and locally impaired by IL-6. Nat Rev Rheumatol 9:505.

Kadota T, Shingo T, Yasuhara T, Tajiri N, Kondo A, Morimoto T, Yuan WJ, Wang F, Baba T, Tokunaga K, Miyoshi Y, Date I. 2009. Continuous intraventricular infusion of erythropoietin exerts neuroprotective/rescue effects upon Parkinson's disease model of rats with enhanced neurogenesis. Brain Res 1254:120-127.

Kahn MA, De Vellis J. 1994. Regulation of an oligodendrocyte progenitor cell line by the interleukin-6 family of cytokines. Glia 12:87-98.

Kako E, Kaneko N, Aoyama M, Hida H, Takebayashi H, Ikenaka K, Asai K, Togari H, Sobue K, Sawamoto K. 2012. Subventricular zone-derived oligodendrogenesis in injured neonatal white matter in mice enhanced by a nonerythropoietic erythropoietin derivative. Stem Cells 30:2234-2247.

Kalatskaya I, Berchiche YA, Gravel S, Limberg BJ, Rosenbaum JS, Heveker N. 2009. AMD3 100 is a CXCR7 ligand with allosteric agonist properties. Mol Pharmacol 75:12401247

Kang SS, Keasey MP, Arnold SA, Reid R, Geralds J, Hagg T. 2012. Endogenous CNTF mediates stroke-induced adult CNS neurogenesis in mice. Neurobiol Dis 49C:68-78.

Kaplan RN, Psaila B, Lyden D. 2007. Niche-to-niche migration of bone-marrow-derived cells. Trends Mol Med |3:72-8I.

Keswani S, Buldanlioglu U, Fischer A, Reed N, Polley M, Liang H, Zhou C, Jack C, Psaila B, Psaila B, Psaila B, Psaila B, Psaila B, 2004. A novel endogenous erythropoietin mediated pathway prevents axonal degeneration. Ann Neurol 56:815-826.

Khan MZ, Brandimarti R, Musser BJ, Resue DM, Fatatis A, Meucci O. 2003. The chemokine receptor CXCR4 regulates cell-cycle proteins in neurons. J Neurovirol 9:300-314.

Khan MZ, Brandimarti R, Shimizu S, Nicolai J, Crowe E, Meucci O. 2008. The chemokine CXCLI 2 promotes survival of postmitotic neurons by regulating Rb protein. Cell Death Differ 15:1663-1672.

Kiel MJ, Morrison SJ. 2008. Uncertainty in the niches that maintain haematopoietic stem cells. Nat Rev Immunol 8:290-30I.

Kijowski J, Baj-Krzyworzeka M, Majka M, Reca R, Marquez LA, Christofidou-Solomidou M, Janowska-Wieczorek A, Ratajczak MZ. 200I. The SDF-I-CXCR4 axis stimulates VEGF secretion and activates integrins but does not affect proliferation and survival in lymphohematopoietic cells. Stem Cells 19:453-466.

Kim JS. 1996. Cytokines and adhesion molecules in stroke and related diseases. J Neurol Sci 137:69-78.

Kim YH, Chung Jl, Woo HG, Jung YS, Lee SH, Moon CH, Suh-Kim H, Baik EJ. 2010.

Differential regulation of proliferation and differentiation in neural precursor cells by the Jak pathway. Stem Cells 28:1816-1828.

Kim YS, Lee KY, Koh SH, Park CY, Kim HY, Lee YJ, Kim HT, Kim J, Kim MH, Kim KS, Chang $\mathrm{DI}, \mathrm{Kim} \mathrm{SH}$. 2006. The role of matrix metalloproteinase 9 in early neurological worsening of acute lacunar infarction. Eur Neurol 55:I I-15.

Kim SJ, Son TG, Kim K, Park HR, Mattson MP, Lee J. 2007. Interferon-gamma promotes differentiation of neural progenitor cells via the JNK pathway. Neurochem Res 3213991406.

Klein RS, Rubin JB. 2004. Immune and nervous system CXCLI2 and CXCR4: Parallel roles in patterning and plasticity. Trends Immunol 25:306-3/4.

Koivuniemi R, Mäkelä J, Hokkanen ME, Bruelle C, Ho TH, Ola R, Korhonen L, Schröder J, Kataoka H, Lindholm D. 20I3. Hepatocyte growth factor activator inhibitor-I is induced by bone morphogenetic proteins and regulates proliferation and cell fate of neural progenitor cells. PLoS One. 8:e56117.

Kokaia Z, Lindvall O. 2013. Neurogenesis after ischaemic brain insults. Curr Opin Neurobiol 13:127-132.834.

Kokaia Z, Martino G, Schwartz M, Lindvall O. 2012. Cross-talk between neural stem cells and immune cells: the key to better brain repair. Nat Neurosci 15:1078-1087.Review. Kokovay E, Goderie S, Wang Y, Lotz S, Lin G, Sun Y, Roysam B, Shen Q, Temple S. 2010. Adult SVZ lineage cells home to and leave the vascular niche via differential responses to SDFI/CXCR4 signaling. Cell Stem Cell 7:163-173.

Krathwohl MD, Kaiser JL. 2004a. Chemokines promote quiescence and survival of human neural progenitor cells. Stem Cells 22:109-||8. 
Krathwohl MD, Kaiser JL. 2004b. HIV-I promotes quiescence in human neural progenitor cells. J Infect Dis 190:216-226. Epub 2004 Jun 22. Erratum in: J Infect Dis. 190:2198. Krtolica A, Larocque N, Genbacev O, Ilic D, Coppe JP, Patil CK, Zdravkovic T, McMaster M, Campisi J, Fisher SJ. 20II. GRO $\alpha$ regulates human embryonic stem cell self-renewal or adoption of a neuronal fate. Differentiation 81:222-232.

Krüger C, Laage R, Pitzer C, Schäbitz WR, Schneider A. 2007. The hematopoietic factor GMCSF (granulocyte-macrophage colony-stimulating factor) promotes neuronal differentiation of adult neural stem cells in vitro. BMC Neurosci 8:88.

Kucia M, Ratajczak J, Ratajczak MZ. 2005a. Bone marrow as a source of circulating CXCR4+ tissue-committed stem cells. Biol Cell 97:133-146. Review.

Kucia M, Reca R, Miekus K, Wanzeck J, Wojakowski W, Janowska-Wieczorek A, Ratajczak J, Ratajczak MZ. 2005b. Trafficking of normal stem cells and metastasis of cancer stem cells involve similar mechanisms: Pivotal role of the SDF-I-CXCR4 axis. Stem Cells 23:879894.

Kucia M, Zhang YP, Reca R, Wysoczynski M, Machalinski B, Majka M, Ildstad ST, Ratajczak J, Shields CB, Ratajczak MZ. 2006. Cells enriched in markers of neural tissue-committed stem cells reside in the bone marrow and are mobilized into the peripheral blood following stroke. Leukemia 20:18-28.

Kuge A, Takemura S, Kokubo Y, Sato S, Goto K, Kayama T. 2009. Temporal profile of neurogenesis in the subventricular zone, dentate gyrus and cerebral cortex following transient focal cerebral ischemia. Neurol Res 31:969-976.

Lacar B, Herman P, Platel JC, Kubera C, Hyder F, Bordey A. 2012. Neural progenitor cells regulate capillary blood flow in the postnatal subventricular zone. J Neurosci 32:1643516448.

Lagane B, Ballet S, Planchenault T, Balabanian K, Le Poul E, Blanpain C, Percherancier Y, Staropoli I, Vassart G, Oppermann M, Parmentier M, Bachelerie F. 2005. Mutation of the DRY motif reveals different structural requirements for the CC chemokine receptor 5mediated signaling and receptor endocytosis. Mol Pharmacol 67:1966-1976.

Lagane B, Chow KY, Balabanian K, Levoye A, Harriague J, Planchenault T, Baleux F, GuneraSaad N, Arenzana-Seisdedos F, Bachelerie F. 2008. CXCR4 dimerization and betaarrestin-mediated signaling account for the enhanced chemotaxis to CXCLI2 in WHIM syndrome. Blood I 12:34-44.

Lapidot T, Dar A, Kollet O. 2005. How do stem cells find their way home? Blood 106:19011910.

Lazarini F, Tham TN, Casanova P, Arenzana-Seisdedos F, Dubois-Dalcq M. 2003. Role of the alpha-chemokine stromal cell-derived factor (SDF-I) in the developing and mature central nervous system Glia 42:139-148.

Leconte C, Bihel E, Lepelletier FX, Bouët V, Saulnier R, Petit E, Boulouard M, Bernaudin M, Schumann-Bard P. 201 I. Comparison of the effects of erythropoietin and its carbamylated derivative on behaviour and hippocampal neurogenesis in mice. Neuropharmacology 60:354-364.

Leong SY, Turnley AM. 20II. Regulation of adult neural precursor cell migration. Neurochem Int. 59:382-393.

Levison SW, Rothstein RP, Romanko MJ, Snyder MJ, Meyers RL, Vannucci SJ. 200I. Hypoxia/ ischemia depletes the rat perinatal subventricular zone of oligodendrocyte progenitors and neural stem cells. Dev Neurosci 23:234-247.

Levoye A, Balabanian K, Baleux F, Bachelerie F, Lagane B. 2009. CXCR7 heterodimerizes with CXCR4 and regulates CXCL I 2-mediated G protein signaling. Blood I I 3:6085-6093. Li M, Hale JS, Rich JN, Ransohoff RM, Lathia JD. 2012. Chemokine CXCLI2 in neurodegenerative diseases: An SOS signal for stem cell-based repair. Trends Neurosci 35:619-628.

Liao ZB, Zhi XG, Shi OH, He ZH. 2008. Recombinant human erythropoietin administration protects cortical neurons from traumatic brain injury in rats. Eur ] Neurol 15:140-149. protects cortical neurons from traumatic brain injury in rats. Eur J Neurol 15:140-149.
Lichtenwalner RJ, Parent JM. 2006. Adult neurogenesis and the ischemic forebrain. J Cereb Blood Flow Metab 26: I-20.

Lim DA, Tramontin AD, Trevejo JM, Herrera DG, Garcia-Verdugo JM, Alvarez-Buylla A. 2000. Noggin antagonizes BMP signaling to create a niche for adult neurogenesis. Neuron 28:713-726.

Lindvall O, Kokaia Z, Martinez-Serrano A. 2004. Stem cell therapy for human neurodegenerative disorders-how to make it work. Nat Med 10:S42-S50.Review.

Liu X, Bolteus AJ, Balkin DM, Henschel O, Bordey A. 2006. GFAP-expressing cells in the postnatal subventricular zone display a unique glial phenotype intermediate between radial glia and astrocytes. Glia 54:394-4I0.

Liu XS, Chopp M, Santra M, Hozeska-Solgot A, Zhang RL, Wang L, Teng H, Lu M, Zhang ZG. 2008a. Functional response to SDFI alpha through over-expression of CXCR4 on adult subventricular zone progenitor cells. Brain Res 1226:18-26.

Liu XS, Chopp M, Santra M, Hozeska-Solgot A, Zhang RL, Wang L, Teng H, Lu M, Zhang LZG. 20I2. Ischemic postconditioning diminishes matrix metalloproteinase 9 expression and attenuates loss of the extracellular matrix proteins in rats following middle cerebral artery occlusion and reperfusion. CNS Neurosci Ther 18:855-863.

Liu XS, Zhang ZG, Zhang RL, Gregg SR, Wang L, Teng H, Lu M, Zhang ZG. 2007. Chemokine ligand 2 (CCL2) induces migration and differentiation of subventricular zone cells after stroke. J Neurosci Res 85:2120-2125.

Liu LY, Zheng H, Xiao HL, She ZJ, Zhao SM, Chen ZL, Zhou GM. 2008b. Comparison of blood-nerve barrier disruption and matrix metalloprotease- 9 expression in injured central and peripheral nerves in mice. Neurosci Lett 434:155-159.

López-Bendito G, Sánchez-Alcañiz JA, Pla R, Borrell V, Picó E, Valdeolmillos M, Marín O. 2008. Chemokine signaling controls intracortical migration and final distribution of GABAergic interneurons. J Neurosci 28:1613-1624.

Lopez-llasaca M, Crespo P, Pellici PG, Gutkind JS, Wetzker R. 1997. Linkage of G proteincoupled receptors to the MAPK signaling pathway through PI 3-kinase gamma. Science 275:394-397.

Lowenstein DH, Arsenault L. 1996. The effects of growth factors on the survival and differentiation of cultured dentate gyrus neurons. J Neurosci 16:1759-1769.

Lu M, Grove EA, Miller RJ. 2002. Abnormal development of the hippocampal dentate gyrus in mice lacking the CXCR4 chemokine receptor. PNAS 99:7090-7095.

Lum M, Croze E, Wagner C, McLenachan S, Mitrovic B, Turnley AM. 2009. Inhibition of neurosphere proliferation by IFNgamma but not IFNbeta is coupled to neuronal differentiation. I Neuroimmunol 206:32-38.

Ma XJ, Cheng JW, Zhang J, Liu AJ, Liu W, Guo W, Shen FM, Lu GC. 2012. E-selectin deficiency attenuates brain ischemia in mice. CNS Neurosci Ther 18:903-908.

$\mathrm{Ma}$ Q, Jones D, Borghesani PR, Segal RA, Nagasawa T, Kishimoto T, Bronson RT, Springer TA. 1998. Impaired B-lymphopoiesis, myelopoiesis, and derailed cerebellar neuron migration in CXCR4- and SDF-I-deficient mice. Proc Natl Acad Sci USA 95:9448-9453.

Mastroianni CM, Liuzzi GM. 2007. Matrix metalloproteinase dysregulation in HIV infection: Implications for therapeutic strategies. Trends Mol Med 13:449-459.

Mellado M, Girard JP, Martinez AC. 2003. CCR7-mediated physiological lymphocyte homing involves activation of a tyrosine kinase pathway. Blood 101:38-44.
Mellado M, Rodriguez-Frade JM, Aragay A, del Real G, Martin AM, Vila-Coro AJ, Serrano A, Mayor F, Jr, Martinez AC. 1998. The chemokine monocyte chemotactic protein I triggers Janus kinase 2 activation and tyrosine phosphorylation of the CCR2B receptor. J Immunol 161:805-813.

Merino JJ, Gutiérrez-Fernández M, Rodríguez-Frutos B, Alvarez-Grech J, Alcalde ME, Vallejo-Cremades MT, Díez-Tejedor E. 20I la. CXCR4/SDF-I $\alpha$-chemokine regulates neurogenesis and/or angiogenesis within the vascular niche of ischemic rats; however, does SDF-I $\alpha$ play a role in repair? Int J Stroke 6:466-467.

Merino JJ, Gutierrez M, Rodríguez-Frutos B, Gonzalez G, Díez-Tejedor E. 2009. Brain porcine peptide (cerebrolisyn) modulates stromal cell derivate alpha I alpha/CXCR4 proinflammatory chemokines in stroke and prevents apoptosis. Cephalalgia 29:12.

Merino JJ, Khan MZ, Bartolomé F, Fatatis A, Meucci O. 2008. Fractalkine regulates Neural Cell Adhesion Molecule -NCAM 180 - and PSA-NCAM levels in cortical neurons at 6 DIV: Regulation by chemokines "in vivo" and "in vitro". FASEB J 22:449.

Merino JJ, Largo C, Caz V, Ibarra L, Posadas S, de Miguel E. 20I Ib. Growth hormone increases neural cell adhesion polysialylation state in the dentate gyrus of $\gamma$-irradiated rats. Synapse 65:1239-1243.

Miller FD, Gauthier AS. 2007. Timing is everything: Making neurons versus glia in the developing cortex. Neuron 54:357-369.

Miller FD, Gauthier-Fisher A. 2009. Home at last: Neural stem cell niches defined. Cell Stem Cell 4:507-510.

Mohle R, Bautz F, Rafii S, Moore MA, Brugger W, Kanz L. 1998. The chemokine receptor CXCR-4 is expressed on CD34+ hematopoietic progenitors and leukemic cells and mediates transendothelial migration induced by stromal cell-derived factor-I. Blood 91:4523-4530.

Moriguchi M, Hissong BD, Gadina M, Yamaoka K, Tiffany HL, Murphy PM, Candotti F, O'Shea J. 2005. CXCLI2 signaling is independent of Jak2 and Jak3. J Biol Chem 280: 17408-174I4 Nagase H. 1997. Activation mechanisms of matrix metalloproteinases. Biol Chem 378:15I160.

Nakai-Futatsugi Y, Niwa H. 2013. Transcription factor network in embryonic stem cells: Heterogeneity under the stringency. Biol Pharm Bull 36:166-170.

Nakamura N, Ramaswamy S, Vazquez F, Signoretti S, Loda M, Sellers WR. 2000. Forkhead transcription factors are critical effectors of cell death and cell cycle arrest downstream of PTEN. Mol Cell Biol 20:8969-8982.

Netelenbos T, van den Born J, Kessler FL, Zweegman S, Merle PA, van Oostveen JW, Zwaginga JJ, Huijgens PC, Dräger AM. 2003. Proteoglycans on bone marrow endothelial cells bind and present SDF-I towards hematopoietic progenitor cells. Leukemia 17:175184.

Ni HT, Hu S, Sheng WS, Olson JM, Cheeran MC, Chan AS, Lokensgard JR, Peterson PK. 2004. High-level expression of functional chemokine receptor CXCR4 on human neural precursor cells. Brain Res Dev Brain Res 152:159-169.

Nieto M, Monuki ES, Tang H, Imitola J, Haubst N, Khoury SJ, Cunningham J, Gotz M, Walsh CA. 2004. Expression of Cux-I and Cux-2 in the subventricular zone and upper layers II-IV of the cerebral cortex. J Comp Neurol 479:168-180.

Ohab JJ, Fleming S, Blesch A, Carmichael ST. 2006. A neurovascular niche for neurogenesis after stroke. J Neurosci 26:13007-13016.

Oshima K, Teo DT, Senn P, Starlinger V, Heller S. 2007. LIF promotes neurogenesis and maintains neural precursors in cell populations derived from spiral ganglion stem cells. BMC Dev Biol 7:112.

Otto VI, Gloor SM, Frentzel S, Gilli U, Ammann E, Hein AE, Folkers G, Trentz O, Kossmann T, Morganti-Kossmann MC. 2002. The production of macrophage inflammatory protein-2 induced by soluble intercellular adhesion molecule-I in mouse astrocytes is mediated by src tyrosine kinases and p42/44 mitogen-activated protein kinase. J Neurochem 80:824834 .

Owens T, Babcock AA, Millward JM. 2005. Toft-Hansen H 48: I78-184.

Paling NR, Wheadon H, Bone HK, Welham MJ. 2004. Regulation of embryonic stem cell self-renewal by hosphoinositide 3-kinase-dependent signaling. J Biol Chem 279: 48063-48070.

Pankratova S, Gu B, Kiryushko D, Korshunova I, Kùhler LB, Rathje M, Bock E, Berezin V. 2012. A new agonist of the erythropoietin receptor, Epo bis, induces neurite outgrowth and promotes neuronal survival. J Neurochem 121:915-923.

Pannu R, Christie DK, Barbosa E, Singh I, Singh AK. 2007. Post-trauma Lipitor treatment prevents endothelial dysfunction, facilitates neuroprotection, and promotes locomotor recovery following spinal cord injury. J Neurochem 101:182-200.

Paredes MF, Li G, Berger O, Baraban SC, Pleasure SJ. 2006. Stromal-derived factor-I CXCLI2) regulates laminar position of Cajal-Retzius cells in normal and dysplastic brains. J Neurosci 26:9404-94I2.

Peng H, Huang Y, Rose J, Erichsen D, Herek S, Fujii N, Tamamura H, Zheng J. 2004. Stromal cell-derived factor I-mediated CXCR4 signaling in rat and human cortical neural progenitor cells. J Neurosci Res 76:35-50.

Peng H, Sun L, Jia B, Lan X, Zhu B, Wu Y, Zheng J. 20II. HIV-I-infected and immuneactivated macrophages induce astrocytic differentiation of human cortical neural progenitor cells via the STAT3 pathway. PLoS One 6:e 19439.DOI: I0.137I/journal. pone.0019439.

Peng H, Wu Y, Duan Z, Ciborowski P, Zheng JC. 20I2. Proteolytic processing of SDF-I $\alpha$ by matrix metalloproteinase- 2 impairs CXCR4 signaling and reduces neural progenitor cell migration. Protein Cell 3:875-882.

Percherancier Y, Berchiche YA, Slight I, Volkmer-Engert R, Tamamura H, Fujii N, Bouvier M, Heveker N. 2005. Bioluminescence resonance energy transfer reveals ligand-induced conformational changes in CXCR4 homo- and heterodimers. J Biol Chem 280:98959903.

Perederiy JV, Luikart BW, Washburn EK, Schnell E, Westbrook GL. 20I3. Neural injury alters proliferation and integration of adult-generated neurons in the dentate gyrus. J Neurosci 33:4754-4767.

Pignatelli A, Belluzzi O. 2010. Neurogenesis in the Adult Olfactory Bulb. In: Menini A, editor. The Neurobiology of Olfaction. Boca Raton (FL): CRC Press. Chapter I I.

Porcile C, Bajetto A, Barbieri F, Barbero S, Bonavia R, Biglieri M, Pirani P, Florio T, Schettini G. 2005. Stromal cell-derived factor-I alpha (SDF-I alpha/CXCLI2) stimulates ovarian cancer cell growth through the EGF receptor transactivation. Exp Cell Res 308:24I-253.

Ramirez-Castillejo C, Sanchez-Sanchez F, Andreu-Agullo C, Ferron SR, Aroca-Aguilar JD, Sanchez P, Mira H, Escribano J, Farinas I. 2006. Pigment epithelium-derived factor is a niche signal for neural stem cell renewal. Nat Neurosci 9:331-339.

Ransome MI, Turnley AM. 2007. Systemically delivered erythropoietin transiently enhances adult hippocampal neurogenesis. J Neurochem 102:1953-1965.

Rao S, Sengupta R, Choe EJ, Woerner BM, Jackson E, Sun T, Leonard J, Piwnica-Worms D, Rubin JB. 2012. CXCLI2 mediates trophic interactions between endothelial and tumor cells in glioblastoma. PLoS One 7:e33005.Epub 2012 Mar 12. 
Ratajczak MZ, Reca R, Wysoczynski M, Yan J, Ratajczak J. 2006. Modulation of the SDF-ICXCR4 axis by the third complement component (C3)-implications for trafficking of CXCR4+ stem cells. Exp Hematol 34:986-995.Review.

Réaux-Le Goazigo A, Van Steenwinckel J, Rostène W, Mélik Parsadaniantz S. 2013. Current status of chemokines in the adult CNS. Prog Neurobiol 104:67-92.

Reed JR, Stone MD, Beadnell TC, Ryu Y, Griffin TJ, Schwertfeger KL. 20I2. Fibroblast growth factor receptor I activation in mammary tumor cells promotes macrophage recruitment in a CX3CLI-dependent manner. PLoS One 7:e45877.

Reiss K, Mentlein R, Sievers J, Hartmann D. 2002. Stromal cell-derived factor I is secreted by meningeal cells and acts as chemotactic factor on neuronal stem cells of the cerebellar external granular layer. Neuroscience 1 15:295-305.

Reuter B, Rodemer C, Grudzenski S, Couraud PO, Weksler B, Romero IA, Meairs S, Bugert P, Hennerici MG, Fatar M. 20I3. Temporal profile of matrix metalloproteinases and their inhibitors in a human endothelial cell culture model of cerebral ischemia. Cerebrovasc Dis 35:514-520.

Robin AM, Zhang ZG, Wang L, Zhang RL, Katakowski M, Zhang L, Wang Y, Zhang C, Chopp M. 2006. Stromal cell-derived factor I lalpha mediates neural progenitor cell motility after focal cerebral ischemia. J Cereb Blood Flow Metab 26:125-134.

Rose RA, Jiang H, Wang X, Helke S, Tsoporis JN, Gong N, Keating SC, Parker TG, Backx PH, Keating A. 2008. Bone marrow-derived mesenchymal stromal cells express cardiacspecific markers, retain the stromal phenotype, and do not become functional cardiomyocytes in vitro. Stem Cells 26:2884-2892.

Rostène W, Kitabgi P, Parsadaniantz SM. 2007. Chemokines: A new class of neuromodulator? Nat Rev Neurosci 8:895-903.

Saaltink DJ, Håvik B, Verissimo CS, Lucassen PJ, Vreugdenhil E. 2012. Doublecortin and doublecortin-like are expressed in overlapping and non-overlapping neuronal cell population: Implications for neurogenesis. J Comp Neurol 520:2805-2823.

Sánchez-Martín L, Sánchez-Mateos P, Cabañas C. 2013. CXCR7 impact on CXCLI2 biology and disease. Trends Mol Med 19:12-22.

Sánchez-Mendoza E, Bellver V, Merino JJ, González M, Martínez-Murillo R, Oset-Gasque MJ. 2013. Review: Could neurotransmitters influence neurogenesis and neurorepair after stroke. Neuropathol Appl Neurobiol 39:722-735

Sanders VJ, Everall IP, Johnson RW, Masliah E. 2000. Fibroblast growth factor modulates HIV coreceptor CXCR4 expression by neural cells. HNRC Group. J Neurosci Res 59:67I679.

Saver JL, Fonarow GC, Smith EE, Reeves MJ, Grau-Sepulveda MV, Pan W, Olson DM, Hernandez AF, Peterson ED, Schwamm LH. 20I3. Time to treatment with intravenous tissue plasminogen activator and outcome from acute ischemic stroke. JAMA 309:24802488 .

Schabath H, Runz S, Joumaa S, Altevogt P. 2006. CD24 affects CXCR4 function in pre-B lymphocytes and breast carcinoma cells. J Cell Sci II9:3।4-325

Schanzer A, Wachs FP, Wilhelm D, Acker T, Cooper-Kuhn C, Beck H, Winkler J, Aigner L, Plate KH, Kuhn HG. 2004. Direct stimulation of adult neural stem cells in vitro and neurogenesis in vivo by vascular endothelial growth factor. Brain Pathol 14:237-248. Schioppa T, Uranchimeg B, Saccani A, Biswas SK, Doni A, Rapisarda A, Bernasconi S, Saccani
S, Nebuloni M, Vago L, Mantovani A, Melillo G, Sica A. 2003. Regulation of the chemokine receptor CXCR4 by hypoxia. J Exp Med 198:139|-1402.

Schönemeier B, Schulz S, Hoellt V, Stumm R. 2008. Enhanced expression of the CXCII2/ SDF-I chemokine receptor CXCR7 after cerebral ischemia in the rat brain. J Neuroimmunol 198:39-45.

Schwindt TT, Motta FL, Gabriela FB, Cristina GM, Guimarães AO, Calcagnotto ME, Pesquero JB, Mello LE. 2009. Effects of FGF-2 and EGF removal on the differentiation of mouse neural precursor cells. An Acad Bras Cienc 81:443-452.

Shen Q, Wang Y, Kokovay E, Lin G, Chuang SM, Goderie SK, Roysam B, Temple S. 2008. Adult SVZ stem cells lie in a vascular niche: A quantitative analysis of niche cell-cell interactions. Cell Stem Cell 3:289-300.

Shimazaki T, Shingo T, Weiss S. 200I. The ciliary neurotrophic factor/leukemia inhibitory factor/gp I30 receptor complex operates in the maintenance of mammalian forebrain neural stem cells. J Neurosci 21:7642-7653.

Simizu S, Nicolai J, Fatatis A, Cook A, Hippensteel R, Meucci O. 2010. Cortical neurons homeostais by SDF/CXCLI 2 in fractalkine/CX3CRI regulation of interations between Chemokines. J Biol Chem 285: 10563-10571.

Shin JW, Lee JK, Lee JE, Min WK, Schuchman EH, Jin HK, Bae JS. 20II. Combined effects of hematopoietic progenitor cell mobilization from bone marrow by granulocyte colony stimulating factor and AMD3100 and chemotaxis into the brain using stromal cell-derived factor- $I \alpha$ in an Alzheimer's disease mouse model. Stem Cells 29:1075-1089.

Shingo T, Sorokan ST, Shimazaki T, Weiss S. 200I. Erythropoietin regulates the in vitro and in vivo production of neuronal progenitors by mammalian forebrain neural stem cells. J Neurosci 21:9733-9743.

Siegenthaler JA, Pleasure SJ. 2010. There's no place like home for a neural stem cell. Cell Stem Cell 7:141-143.

Smadja DM, Bieche I, Uzan G, Bompais H, Muller L, Boisson-Vidal C, Vidaud M, Aiach M, Gaussem P. 2005. PAR-I activation on human late endothelial progenitor cells enhances angiogenesis in vitro with upregulation of the SDF-I/CXCR4 system. Arterioscler Thromb Vasc Biol 25:232I-2327.

Snapyan M, Lemasson M, Brill MS, Blais M, Massouh M, Ninkovic J, Gravel C, Berthod F, Gotz M, Barker PA, Parent A, Saghatelyan A. 2009. Vasculature guides migrating neuronal precursors in the adult mammalian forebrain via brainderived neurotrophic factor signaling. J Neurosci 29:4172-4188.

Son BR, Marquez-Curtis LA, Kucia M, Wysoczynski M, Turner AR, RatajczakJ, Ratajczak MZ, Janowska-Wieczorek A. 2006. Migration of bone marrow and cord blood mesenchymal stem cells in vitro is regulated by stromal-derived factor-I-CXCR4 and hepatocyte growth factor-cmet axes and involves matrix metalloproteinases. Stem Cells 24:1254grow

Song JH, Wang CX, Song DK, Wang P, Shuaib A, Hao C. 2005. Interferon gamma induces neurite outgrowth by up-regulation of $\mathrm{p} 35$ neuron-specific cyclin-dependent kinase 5 activator via activation of ERKI/2 pathway. J Biol Chem 280:12896-1290I.

Soriano SF, Serrano A, Hernanz-Falcon P, Martin de Ana A, Monterrubio M, Martinez C, Rodriguez-Frade JM, Mellado M. 2003. Chemokines integrate JAK/STAT and G-protein pathways during chemotaxis and calcium flux responses. Eur I Immunol 33:1328-1333.

Stein JV, Soriano SF, M'Rini C, Nombela-Arrieta C, de Buitrago GG, Rodriguez-Frade JM, Mellado M, Girard JP, Martinez AC. 2003. CCR7-mediated physiological lymphocyte homing involves activation of a tyrosine kinase pathway. Blood 101:38-44.

Stephens CL, Toda H, Palmer TD, DeMarse TB, Ormerod BK. 2012. Adult neural progenitor cells reactivate superbursting in mature neural networks. Exp Neurol 234:20-30.

Stroemer P, Patel S, Hope A, Oliveira C, Pollock K, Sinden J. 2009. The neural stem cell line $\mathrm{CTX} 0 \mathrm{E} 03$ promotes behavioral recovery and endogenous neurogenesis after experimental stroke in a dose-dependent fashion. Neurorehabil Neural Repair 23:895909.

Stumm RK, Zhou C, Ara T, Lazarini F, Dubois-Dalcq M, Nagasawa T, Höllt V, Schulz S. 2003 CXCR4 regulates interneuron migration in the developing neocortex. J Neurosci 23:5123-5130

Sundberg M, Andersson PH, Åkesson E, Odeberg J, Holmberg L, Inzunza J, Falci S, Öhman J, Suuronen R, Skottman H, Lehtimäki K, Hovatt O, Narkilahti S, Sundström E. 2011 . Markers of pluripotency and differentiation in human neural precursor cells derived from embryonic stem cells and CNS tissue. Cell Transplant 20:177-191.

Suyama T, Furuya M, Nishiyama M, Kasuya Y, Kimura S, Ichikawa T, Ueda T, Nikaido T, Ito H, Ishikura H. 2005. Upregulation of the interferon gamma (IFN-gamma)-inducible chemokines IFNinducible T-cell alpha chemoattractant and monokine induced by IFNgamma and of their receptor CXC receptor 3 in human renal cell carcinoma. Cancer 103:258-267.

Taga T, Fukuda S. 2005. Role of IL-6 in the neural stem cell differentiation. Clin Rev Allergy Immunol 28:249-256.

Taga T, Kishimoto T. 1997. GpI30 and the interleukin-6 family of cytokines. Annu Rev Immunol 15:797-819.Review.

Takasawa K, Kitagawa K, Yagita Y, Sasaki T, Tanaka S, Matsushita K, Ohstuki T, Miyata T, Okano H, Hori M, Matsumoto M. 2002. Increased proliferation of neural progenitor cells but reduced survival of newborn cells in the contralateral hippocampus after focal cerebral ischemia in rats. J Cereb Blood Flow Metab 22:299-307.

Talaverón R, Matarredona ER, de la Cruz RR, Pastor AM. 2013. Neural progenitor cell implants modulate vascular endothelial growth factor and brain-derived neurotrophic factor expression in rat axotomized neurons. PLoS One 8:e54519.

Tanegashima K, Suzuki K, Nakayama Y, Tsuji K, Shigenaga A, Otaka A, Hara T. 2013. CXCLI 4 is a natural inhibitor of the CXCLI2-CXCR4 signaling axis. FEBS Lett 587:173I1735

Tavazoie M, Van der Veken L, Silva-Vargas V, Louissaint M, Colonna L, Zaidi B, Garcia-

Verdugo JM, Doetsch F. 2008. A specialized vascular niche for adult neural stem cells. Cell Stem Cell 3:279-288.

Tham TN, Lazarini F, Franceschini IA, Lachapelle F, Amara A, Dubois-Dalcq M. 200 I.

Developmental pattern of expression of the alpha chemokine stromal cell-derived factor I in the rat central nervous system. Eur J Neurosci 13:845-856.

Tessier-Lavigne M, Goodman CS. 1996. The molecular biology of axon guidance. Science 274: II 23-1133.

Thored P, Arvidsson A, Cacci E, Ahlenius H, Kallur T, Darsalia V, Ekdahl CT, Kokaia Z, Lindvall O. 2006. Persistent production of neurons from adult brain stem cells during recovery after stroke. Stem Cells 24:739-747.

Tissir F, Wang CE, Goffinet AM. 2004. Expression of the chemokine receptor Cxcr4 mRNA during mouse brain development. Brain Res Dev Brain Res |49:63-7|.

Tiveron MC, Cremer H. 2008. CXCLI2/CXCR4 signalling in neuronal cell migration. Curr Opin Neurobiol 18:237-244.

Tiveron MC, Rossel M, Moepps B, Zhang YL, Seidenfaden R, Favor J, König N, Cremer H. 2006. Molecular interaction between projection neuron precursors and invading interneurons via stromal-derived factor I (CXCLI2)/CXCR4 signaling in the cortical subventricular zone/intermediate zone. J Neurosci 26:13273-13278.

Tonchev AB, Yamashima T, Sawamoto K, Okano H. 2005. Enhanced proliferation of progenitor cells in the subventricular zone and limited neuronal production in the striatum and neocortex of adult macaque monkeys after global cerebral ischemia. J Neurosci Res 81:776-788.

Tran PB, Banisadr G, Ren D, Chenn A, Miller RJ. 2007. Chemokine receptor expression by neural progenitor cells in neurogenic regions of mouse brain. J Comp Neurol 500:10071033.

Tsai PT, Ohab JJ, Kertesz N, Groszer M, Matter C, Gao J, Liu X, Wu H, Carmichael ST. 2006. A critical role of erythropoietin receptor in neurogenesis and post-stroke recovery. J Neurosci 26:1269-1274.

Turbic A, Leong SY, Turnley AM. 20I I. Chemokines and inflammatory mediators interact to regulate adult murine neural precursor cell proliferation, survival and differentiation. PLoS ONE 6:e25406.

Udagawa J, Nimura M, Otani H. 2006. Leptin affects oligodendroglial development in the mouse embryonic cerebral cortex. Neuro Endocrinol Lett 27:177-182.

van Biesen T, Luttrell LM, Hawes BE, Lefkowitz RJ. 1996. Mitogenic signaling via G proteincoupled receptors. Endocr Rev 17:698-7/4.

Van den Steen PE, Dubois B, Nelissen I, Rudd PM, Dwek RA, Opdenakker G. 2002. Biochemistry and molecular biology of gelatinase B or matrix metalloproteinase-9 (MMP9). Crit Rev Biochem Mol Biol 37:375-536.

Venstrom KA, Reichardt LF. 1993. Extracellular matrix. 2: Role of extracellular matrix molecules and their receptors in the nervous system. FASEB J 7:996-1003.

Vila-Coro AJ, Rodriguez-Frade JM, Martin De Ana A, Moreno-Ortiz MC, Martinez AC. 1999 The chemokine SDF- I alpha triggers CXCR4 receptor dimerization and activates the JAK STAT pathway. FASEB J 13:1699-1710.

Virgintino D, Errede M, Rizzi M, Girolamo F, Strippoli M, Wälchli T, Robertson D, Frei K, Roncali L. 2013. The CXCLI2/CXCR4/CXCR7 ligand-receptor system regulates neuroglio-vascular interactions and vessel growth during human brain development. J Inherit Metab Dis 36:455-466.

Vitkovic L, Bockaert J, Jacque C. 2000. "Inflammatory" cytokines: Neuromodulators in normal brain? J Neurochem 74:457-47।.

Voermans C, Anthony EC, Mul E, van der Schoot E, Hordijk P. 200 la. SDF-I-induced actin polymerization and migration in human hematopoietic progenitor cells. Exp Hematol 29:1456-1464

Voermans C, van Hennik PB, van der Schoot CE. 200 Ib. Homing of human hematopoietic stem and progenitor cells: new insights, new challenges? J Hematother Stem Cell Res 10:725-738

Walton RM, Parmentier T, Wolfe JH. 20I3. Postnatal neural precursor cell regions in the rostral subventricular zone, hippocampal subgranular zone and cerebellum of the dog (Canis lupus familiaris). Histochem Cell Biol I39:415-429.

Wang J, Asensio VC, Campbell IL. 2002. Cytokines and chemokines as mediators of protection and injury in the central nervous system assessed in transgenic mice. Curr Top Microbiol Immunol 265:23-48.

Wang J, Shiozawa Y, Wang J, Wang Y, Jung Y, Pienta KJ, Mehra R, Loberg R, Taichman RS. 2008. The role of CXCR7/RDCI as a chemokine receptor for CXCLI 2/SDF-I in prostate cancer. J Biol Chem 283:4283-4294.

Wang L, Zhang Z, Wang Y, Zhang R, Chopp M. 2004. Treatment of stroke with erythropoietin enhances neurogenesis and angiogenesis and improves neurological function in rats. Stroke 35:1732-1737.

Wang L, Zhang ZG, Zhang RL, Gregg SR, Hozeska-Solgot A, LeTourneau Y, Wang Y, Chopp M. 2006. Matrix metalloproteinase 2 (MMP2) and MMP9 secreted by erythropoietin- 
activated endothelial cells promote neural progenitor cell migration. J Neurosci 26:59966003.

Wang Y, Li G, Stanco A, Long JE, Crawford D, Potter GB, Pleasure SJ, Behrens T, Rubenstein JL. 20I I. CXCR4 and CXCR7 have distinct functions in regulating interneuron migration. Neuron 69:6I-76.

Warner KA, Miyazawa M, Cordeiro MM, Love WJ, Pinsky MS, Neiva KG, Spalding AC, Nör JE. 2008. Endothelial cells enhance tumor cell invasion through a crosstalk mediated by CXC chemokine signaling. Neoplasia 10:131-139.

Weiss N, Deboux C, Chaverot N, Miller F, Baron-Van Evercooren A, Couraud PO Cazaubon S. 2010. IL8 and CXCLI 3 are potent chemokines for the recruitment of human neural precursor cells across brain endothelial cells. J Neuroimmunol 223:131-|34.

Whitney NP, Eidem TM, Peng H, Huang Y, Zheng JC. 2009. Inflammation mediates varying effects in neurogenesis: Relevance to the pathogenesis of brain injury and neurodegenerative disorders. J Neurochem 108:1343-1359.

Widera D, Grimm WD, Moebius JM, Mikenberg I, Piechaczek C, Gassmann G, Wolff NA Thévenod F, Kaltschmidt C, Kaltschmidt B. 2007. Highly efficient neural differentiation of human somatic stem cells, isolated by minimally invasive periodontal surgery. Stem Cells Dev 16:447-460.

Widera D, Holtkamp W, Entschladen F, Niggemann B, Zanker K, Kaltschmidt B, Kaltschmidt C. 2004. MCP-I induces migration of adult neural stem cells. Eur J Cell Biol 83:38I-387. Wong M, Fish EN. 1998. RANTES and MIP-Ialpha activate stats in T cells. J Biol Chem 273:309-314.

Wong G, Goldshmit Y, Turnley AM. 2004. Interferon-gamma but not TNF alpha promotes neuronal differentiation and neurite outgrowth of murine adult neural stem cells. Exp Neurol 187:17I-177.

Wong D, Korz W. 2008. Translating an antagonist of chemokine receptor CXCR4: From bench to bedside. Clin Cancer Res I4:7975-7980.

Wu Y, Peng H, Cui M, Whitney NP, Huang Y, Zheng JC. 2009. CXCLI2 increases human neural progenitor cell proliferation through Akt-I/FOXO3a signaling pathway. J Neurochem 109:1157-1167.

Wu X, Yu T, Bullard DC, Kucik DF. 2012. SDF-I $\alpha$ (CXCLI2) regulation of lateral mobility contributes to activation of LFA-I adhesion. Am J Physiol Cell Physiol 303:C666-C672. DOI: 10.1152/ajpcell.00190.2012.

Wysoczynski M, Reca R, Ratajczak J, Kucia M, Shirvaikar N, Honczarenko M, Mills M, Wanzeck J, Janowska-Wieczorek A, Ratajczak MZ. 2005. Incorporation of CXCR4 into membrane lipid rafts primes homing-related responses of hematopoietic stem/progenitor cells to an SDF-I gradient. Blood 105:40-48.

Wysoczynski M, Kucia M, Ratajczak J, Ratajczak MZ. 2007. Cleavage fragments of the third yysoczynski M, Kucia M, Ratajczak J, Ratajczak MZ. 2007. Cleavage fragments of the thir
complement component (C3) enhance stromal derived factor-I (SDF-I)-mediated platelet production during reactive postbleeding thrombocytosis. Leukemia 21:973-982.
Xiong Y, Mahmood A, Lu D, Qu C, Goussev A, Schallert T, Chopp M. 2007. Role of gender in outcome after traumatic brain injury and therapeutic effect of erythropoietin in mice. Brain Res II85:30I-312.

Yang W, Dolloff NG, El-Deiry WS. 2008b. ERK and MDM2 prey on FOXO3a. Nat Cell Biol 10:125-126.

Yu TW, Bargmann Cl. 200 I. Dynamic regulation of axon guidance. Nat Neurosci 4: I I69-1 I 76

Zacharek A, Chen J, Cui X, Li A, Li Y, Roberts C, Feng Y, Gao Q, Chopp M. 2007. Angiopoietin I/Tie2 and VEGF/FIk I induced by MSC treatment amplifies angiogenesis and vascular stabilization after stroke. J Cereb Blood Flow Metab 27:1684-|69|.Epub 2007 Mar 14

Zacharek A, Chen J, Zhang C, Cui X, Roberts C, Jiang H, Teng H, Chopp M. 2006. Nitric oxide regulates Angiopoietin I/Tie2 expression after stroke. Neurosci Lett 404:28-32.

Zhang Q, Liu G, Wu Y, Sha H, Zhang P, Jia J. 20II. BDNF promotes EGF-induced proliferation and migration of human fetal neural stem/progenitor cells via the PI3K/Akt pathway. Molecules 16:10146-10156.

Zhang K, McQuibban GA, Silva C, Butler GS, Johnston JB, Holden J, Clark-Lewis I, Overall CM, Power C. 2003. HIV-induced metalloproteinase processing of the chemokine stromal cell derived factor-I causes neurodegeneration. Nat Neurosci 6:1064-107I.

Zhang R, Wang L, Zhang L, Chen J, Zhu Z, Zhang Z, Chopp M. 2003. Nitric oxide enhances angiogenesis via the synthesis of vascular endothelial growth factor and cGMP after stroke in the rat. Circ Res 92:308-313.

Zhang ZG, Zhang L, Tsang W, Goussev A, Powers C, Ho KL, Morris D, Smyth SS, Coller BS, Chopp M. 200I. Dynamic platelet accumulation at the site of the occluded middle cerebral artery and in downstream microvessels is associated with loss of microvascular integrity after embolic middle cerebral artery occlusion. Brain Res 912:18I-194.

Zhang ZG, Zhang L, Tsang W, Soltanian-Zadeh H, Morris D, Zhang R, Goussev A, Powers C, Yeich T, Chopp M. 2002. Correlation of VEGF and angiopoietin expression with disruption of blood-brain barrier and angiogenesis after focal cerebral ischemia. J Cereb Blood Flow Metab 22:379-392.

Zhao BQ, Wang S, Kim HY, Storrie H, Rosen BR, Mooney DJ, Wang X, Lo EH, Role of matrix metalloproteinases in delayed cortical responses after stroke. Nat Med 12:44I-445.

Zhou B, Han ZC, Poon MC. 2007. Mesenchymal stem/stromal cells (MSC) transfected with stromal derived factor I (SDF-I) for therapeutic neovascularization: Enhancement of cell recruitment and entrapment. Med Hypotheses. Med Hypotheses 68:I268-I27I.

Zhu B, Xu D, Deng X, Chen Q, Huang Y, Peng H, Li Y, jia B, Thoreson WB, Ding W, Ding J, Zhao L, Wang Y, Wavrin KL, Duan S, Zheng J. 20I2. CXCLI2 enhances human neural progenitor cell survival through a CXCR7- and CXCR4-mediated endocytotic signaling pathway. Stem Cells 30:257I-2583.

Zhu Y, Yu T, Zhang XC, Nagasawa T, Wu JY, Rao Y. 2002. Role of the chemokine SDF-I as the meningeal attractant for embryonic cerebellar neurons. Nat Neurosci 5:719-720. 